This item was submitted to Loughborough's Research Repository by the author.

Items in Figshare are protected by copyright, with all rights reserved, unless otherwise indicated.

\title{
Interdisciplinary: challenges and opportunities for design education
}

PLEASE CITE THE PUBLISHED VERSION

https://doi.org/10.1007/s10798-018-9460-5

\section{PUBLISHER}

(C) Springer

\section{VERSION}

AM (Accepted Manuscript)

\section{PUBLISHER STATEMENT}

This work is made available according to the conditions of the Creative Commons Attribution-NonCommercialNoDerivatives 4.0 International (CC BY-NC-ND 4.0) licence. Full details of this licence are available at: https://creativecommons.org/licenses/by-nc-nd/4.0/

\section{LICENCE}

CC BY-NC-ND 4.0

\section{REPOSITORY RECORD}

Self, James, Mark A. Evans, Gyuchan Thomas Jun, and Darren J. Southee. 2019. "Interdisciplinary: Challenges and Opportunities for Design Education”. figshare. https://hdl.handle.net/2134/34080. 


\section{International Journal of Technology and Design Education Interdisciplinary: Challenges \& Opportunities for Design Education \\ --Manuscript Draft--}

Manuscript Number:

Full Title:

Interdisciplinary: Challenges \& Opportunities for Design Education

Article Type:

Original Research Article

Keywords:

Design Education; Interdisciplinary, Pedagogy; Learning Experience, industrial

design, product design

Corresponding Author:

James Andrew Self, Ph.D

Ulsan National Institute of Science and Technology (UNIST)

Ulsan, KOREA, REPUBLIC OF

Corresponding Author Secondary

Information:

Corresponding Author's Institution:

Ulsan National Institute of Science and Technology (UNIST)

Corresponding Author's Secondary Institution:

First Author:

James Andrew Self, Ph.D

First Author Secondary Information:

Order of Authors:

James Andrew Self, Ph.D

Mark Evans

Thomas Jun

Darren Southee

Order of Authors Secondary Information:

Funding Information:

Ulsan National Institute of Science and

Technology

Dr. James Andrew Self

(1.150129.01)

Abstract:

We explore the potential drivers for and barriers to interdisciplinary education in design from the student learning perspective. To achieve this, a series of in-depth student interview studies were conducted at two high profile interdisciplinary design schools in the Republic of Korea and the UK. Results indicated both awareness and synthesis of interdisciplinary perspectives across the two schools. However, these abilities appeared more heavily dependent upon individual student attitudes and interests, compared to the programmes of study themselves. Instructor bias and potential integration issues at school and institutional levels were further cited as challenges to interdisciplinarity. However, results also indicated application as a key driver for the acquisition and synthesis of disciplinary perspectives. Students, within the applied discipline of design, responded well to interdisciplinarity when accompanied by opportunities to integrate disciplinary knowledge through application within their own project works. Implications for interdisciplinary approaches to design education are finally discussed together with suggested avenues for future investigation. 


\title{
Interdisciplinary: Challenges \& Opportunities for Design Education
}

\author{
James A. Self*, Mark Evans**, Thomas Jun**, Darren Southee** \\ *School of Design \& Human Engineering, UNIST, Ulsan, Republic of Korea. \\ E: jaself@unist.ac.kr. T: +82(0)52 2172722
}

**Loughborough Design School, Loughborough University, UK.

\begin{abstract}
We explore the potential drivers for and barriers to interdisciplinary education in design from the student learning perspective. To achieve this, a series of in-depth student interview studies were conducted at two high profile interdisciplinary design schools in the Republic of Korea and the UK. Results indicated both awareness and synthesis of interdisciplinary perspectives across the two schools. However, these abilities appeared more heavily dependent upon individual student attitudes and interests, compared to the programmes of study themselves. Instructor bias and potential integration issues at school and institutional levels were further cited as challenges to interdisciplinarity. However, results also indicated application as a key driver for the acquisition and synthesis of disciplinary perspectives. Students, within the applied discipline of design, responded well to interdisciplinarity when accompanied by opportunities to integrate disciplinary knowledge through application within their own project works. Implications for interdisciplinary approaches to design education are finally discussed together with suggested avenues for future investigation.
\end{abstract}

Keywords: Design Education; Interdisciplinary, Pedagogy; Learning Experience, industrial design, product design

\section{Acknowledgments}

We would like to extend our thanks to all those students at the DHE, UNIST and LDS, Loughborough University that took part in our interview studies. This work was supported by the UNIST Creative Project Fund 1.150129.01. 


\title{
Interdisciplinary: Challenges \& Opportunities for Design Education
}

\begin{abstract}
We explore the potential drivers for and barriers to interdisciplinary education in design from the student learning perspective. To achieve this, a series of in-depth student interview studies were conducted at two high profile interdisciplinary design schools in the Republic of Korea and the UK. Results indicated both awareness and synthesis of interdisciplinary perspectives across the two schools. However, these abilities appeared more heavily dependent upon individual student attitudes and interests, compared to the programmes of study themselves. Instructor bias and potential integration issues at school and institutional levels were further cited as challenges to interdisciplinarity. However, results also indicated application as a key driver for the acquisition and synthesis of disciplinary perspectives. Students, within the applied discipline of design, responded well to interdisciplinarity when accompanied by opportunities to integrate disciplinary knowledge through application within their own project works. Implications for interdisciplinary approaches to design education are finally discussed together with suggested avenues for future investigation.
\end{abstract}

Keywords: Design Education; Interdisciplinary, Pedagogy; Learning Experience, industrial design, product design

\section{Introduction}

Interdisciplinary knowledge acquisition and the accompanying ability to work across disciplines is becoming more important due to increases in the rate of technological advancement and the emergence of the knowledge-based society (Kang, 2008). Within the traditional product/industrial design disciplines it is now recognised that specialised disciplinary skill and knowledge is limited in its ability to address the complex problems often encountered by designers in an increasingly connected world (Mok, 2009; Norman, 2010; Norman \& Klemmer, 2014). For example, how does the emergence of IoT (Internet of Things) products implicate the kinds of skills and knowledge required to develop appropriate IoT design solutions? What opportunities and challenges do increasingly sophisticated communications platforms pose for the future of product design? How does a more systemic view of design (i.e product service system design) implicate the kinds of skills and knowledge required by designers to contribute to the solution of increasingly complex systemic problems (Norman op cit.)?

Due to the potential benefit of interdisciplinarity in design education, there exists a small but growing body of research aimed at exploring pedagogic approaches to interdisciplinary education. For example, Self and Baek (2017) report on the design and implementation of an undergraduate interdisciplinary course (ID201 Design Thinking) undertaken at the School of Design and Human Engineering (DHE) at Ulsan National Institute of Science and Technology (UNIST), Korea. Findings indicate the importance of careful curriculum design and consideration for knowledge integration, together with the role of application within project works as driver for enhanced interdisciplinary learning. 
Lattuca and Knight (2010) investigate interdisciplinarity in design engineering to identify ways in which it is understood by stakeholders, with implications for approaches to interdisciplinary education. Carulli et al. (2013) explore current issues in the application of educational tools and methods that attempt to integrate product design and engineering, describing and validating an integrated framework for interdisciplinary education. Lattuca et al. (2013) identify and apply a set of scales through which interdisciplinary competences are measured.

Other studies of interdisciplinary approaches to curriculum development within industrial/product design have adopted descriptive accounts (Jaeger, Mayrhofer, Kuhlang, \& Matyas, 2013; Kim et al., 2012a; Oehlberg, Leighton, \& Agogino, 2012; Strong, 2012; M. K. Thompson, 2009; Yim, Lee, Brezing, Lower, \& Feldhusen, 2011). For example, Kim et al's (2012), describing an assembly of design and engineering courses at the DHE, UNIST, identify the attainment of increased information/resource application skills. However, the study also indicated reduced student selfconfidence due to a lack of core competencies in the separate disciplines of design and engineering.

Despite the increased attention being given to interdisciplinary approaches to design there has been limited effort applied to the investigation, assessment and understanding of the ecology of interdisciplinary learning. Loughborough Design School (LDS) at Loughborough University, UK and The School of Design and Human Engineering, UNIST, Korea (DHE), each contain faculty members from across design and engineering disciplines as diverse as product design, electronics, mechanical engineering, engineering design, material science, ergonomics and the computer sciences. These various faculty are integrated into undergraduate teaching and learning which attempts to cut across disciplinary boundaries, fostering opportunities for interdisciplinary skill and knowledge acquisition (Bingham, Southee, \& Page, 2015).

The current work reports an interview study of undergraduate students enrolled within interdisciplinary programmes across $L D S$ and the DHE. We examine the opportunities for and challenges to interdisciplinartity as seen from a student learning perspective. To achieve this, we apply criteria for assessing interdisciplinary competencies (L Lattuca, Knight, \& Bergom, 2013) to the design of interview questions. The resulting data-set was then analysed through a grounded approach to define key concepts as drivers for and potential barriers to the success of interdisciplinary approaches to design education at undergraduate level.

\section{Interdisciplinarity, a Definition}

In defining interdisciplinarity in design education, we recognise Repko's (2012) distinction between a multidisciplinary approach and a truly interdisciplinary endeavour. Interdisciplinarity is not a juxtaposition of two or more disciplines, but requires their integration in dissemination of disciplinary skills and knowledge as part of the student learning experience. 
By way of illustration, Lattuca (2001) discusses the analogy of the bowl of fruit compared to a fruit smoothie. Multidisciplinary studies are characterised by the positioning of each discipline (their associated knowledge, frames-of-reference, approaches, methods, accepted practices) alongside one another; the fruits and their position are distinct and separate. Likewise, the positioning of disciplinary knowledge and skill within a programme of study, course or educational approach with different disciplines working alongside, but separately from one another in their dissemination of knowledge (Self \& Baek, 2016). This is contrasted with a fine blending of fruits to produce a recipe for closely integrated interdisciplinarity. Or in other words, an integration of perspectives and approaches through the sharing of knowledge, ideas and skills in the co-development of programmes to best accommodate interdisciplinary perspectives learning.

Interdisciplinarity may also exist at different levels of integration. At one end, multidisciplinary approaches are little more than informal conversations between faculty and students from different disciplines of study, or the sharing of class time within a course between instructors of different disciplines. This contrasts with formal collaborative arrangements whereby careful consideration for the integration of disciplinary knowledge and skill is required, together with active participation from faculty of different disciplines to best stimulate interdisciplinary learning.

Returning to our discussion of the importance of interdisciplinary approaches to design education due to increasing complexity in the problems now facing design (Norman \& Klemmer, 2014), we position the Klein and Newell (1998) definition of interdisciplinarity as ideal for interdisciplinary education in design: 'A process of answering a question, solving a problem, or addressing a topic that is too broad or complex to be dealt with adequately by a single discipline or profession...and draws upon disciplinary perspectives and integrates their insights through construction of a more comprehensive perspective' (Klein \& Newell's 1998, p393-394).

\section{Assessing Interdisciplinary Learning}

With the Klein and Newell (ibid) definition in hand, actionable constructs are required to assess the extent to which interdisciplinarity in design education may be succeeding. Current research on interdisciplinary design and engineering education broadly falls into three types. Prescriptive studies aimed at providing tools and methods to describe, measure and assess interdisciplinarity (Carulli, Bordegoni, \& Cugini, 2013; L Lattuca et al., 2013; Mansilla \& Duraising, 2007; Mansilla \& Gardner, 2003). Descriptive investigations, employing case-study as means to describe examples of interdisciplinarity (Bingham et al., 2015; Jaeger, Mayrhofer, Kuhlang, \& Matyas, 2013; Kim et al., 2012; Lisa Lattuca \& Knight, 2010; Oehlberg, Leighton, \& Agogino, 2012; Thompson, 2009; Tolbert \& Daly, 2013; Yim, Lee, Brezing, Lower, \& Feldhusen, 2011). Works which aim to analyze the factors and principles which underpin attitudes towards interdisciplinarity as a means to provide greater understanding of the phenomena (Adams, Turns, \& Atman, 2003; Kaygan \& nar, 2014; L. R. Lattuca, 2001; L. R. Lattuca, Voight, \& Fath, 2004; Newell, 2001). 
Any investigation of interdisciplinarity is complicated by disagreement on a clear definition of what constitutes interdisciplinary education, much less how to assess its success in instilling interdisciplinary knowledge and competences. Interdisciplinarity has been described as both nostalgia for lost wholeness and a new stage in the evolution of science, whereas others associate interdisciplinarity with the historical quest for unified knowledge (J Klein, 1990). Efforts have, however, been made to provide a theoretical grounding for the assessment of interdisciplinary learning. For example, Mansilla and Gardener (2003) provide three criteria for assessing interdisciplinary competence: work well grounded in the disciplines; work which advances student understanding through integrating more than one disciplinary lens; work which illustrates critical awareness in means the synthesis of disciplinary knowledge. Mansilla and Gardener (ibid) argue that the success of interdisciplinary integration may best be measured by the degree to which it achieves its purpose. Likewise, Lattuca et al. (2013) provide criteria for understanding the nature of interdisciplinary competences among undergraduate engineering students. Based upon this review we synthesis seven criteria for assessing interdisciplinary learning (Table 1).

Table 1 Seven criteria for assessing interdisciplinarity

\begin{tabular}{c|l}
\hline $\begin{array}{c}\text { Criteria to Assess } \\
\text { Interdisciplinarity }\end{array}$ & \multicolumn{1}{c}{ Description } \\
\hline $\begin{array}{c}\text { C01.Awareness of } \\
\text { Disciplinarity }\end{array}$ & $\begin{array}{l}\text { Work being well grounded in disciplines which it draws. The idea that certain } \\
\text { level of disciplinary knowledge required to effectively integrate perspectives, } \\
\text { methods \& practices of two or more disciplines to achieve specific goal. }\end{array}$ \\
\hline $\begin{array}{c}\text { C02. Appreciation of } \\
\text { Disciplinary Perspectives }\end{array}$ & $\begin{array}{l}\text { Process of fostering disciplinary knowledge \& appreciation of disciplinary } \\
\text { perspectives. Moving from general knowledge of discipline to more specific } \\
\text { knowledge of how each of its elements informs insights into the problem }\end{array}$ \\
\hline Disciplinary Limitations & $\begin{array}{l}\text { Means through which interdisciplinary competences may be measured. Critical } \\
\text { reflection upon and awareness of one's own field of study. }\end{array}$ \\
\hline Interdisciplinarity & $\begin{array}{l}\text { Means to solve different problems in various situations. Students able to develop } \\
\text { ability to effectively evaluate effectiveness of interdisciplinary work. }\end{array}$ \\
\hline C05. Finding Common & $\begin{array}{l}\text { Ability to dynamically modify one's own perspectives, world view \& expectations } \\
\text { to accommodate those of others. }\end{array}$ \\
\hline C06. Reflexivity & $\begin{array}{l}\text { Ability to reflect upon one's own choices for defining a given problem; how these } \\
\text { choices may influence framing \& solution development. }\end{array}$ \\
\hline
\end{tabular}

C01. (Awareness of Disciplinarity) draws upon Mansilla and Gardener's (2003) notion of work well grounded in the disciplines upon which it draws, resting upon a premise that a certain level of disciplinary knowledge is required to effectively integrate the perspectives, methods and practices of two or more disciplines to achieve a specific goal. C02. (Appreciation of Disciplinary Perspectives) is described as a process of moving from a general knowledge to more specific knowledge of how disciplinary elements inform problem understanding. C03. (Recognition of Disciplinary Limitations) 
is described by Lattuca et al. (2013) as a critical reflection upon and awareness of one's own discipline through knowledge of other disciplines. C04. (Appropriateness of Interdisciplinarity) refers to an ability to solve different problems in various situations. Students are provided opportunities to develop an aptitude to effectively evaluate the effectiveness of interdisciplinary work. C05. (Finding Common Ground) considers an ability to dynamically modify one's own perspectives, world view and expectations to accommodate those of other disciplines. C06. (Reflexivity) is the ability to more critically reflect upon one's own choices in the definition of a given problem and its solution from various disciplinary perspectives. C07. (Integrative Skill) is an ability to synthesise disciplinary knowledge in order to provide a more comprehensive understanding of the problem together with possible solution directions.

The seven criteria presented in Table 1 provided a theoretical foundation, point of departure and means of assessment for our investigation of interdisciplinarity in design education. In particular, the design of interview questions and discussion of results reflect upon the extent to which our findings reflect the seven criteria in providing opportunities for interdisciplinary student learning.

\section{Student Learning Experience}

Within the literature on knowledge acquisition, four types of knowledge can be identified. First, declarative knowledge (Goel, 2001) describes a type of knowing related to fact i.e. knowing what something is, what its properties are and what they are described as. Procedural knowledge relates to understanding the how of a process; how may it work, be used and/or applied to achieve a required result? Schematic knowledge is concerned with understanding why a thing or process is and/or works in the way that it does. Strategic knowledge relates to a more holistic knowing towards the appropriate application of when, where and how a given understanding may be applied to achieve a required beneficial result or outcome (Kolb, 2014). It is in strategic knowledge that interdisciplinary education may be most effective in dealing with increasingly complex problems. As such, an ability to acquire strategic knowledge appears the aim of an interdisciplinary approach to design education in that it provides opportunities to apply different knowledge and skill to address the various facets of more complex problems.

By necessity, Higher Education Institutions (HEIs) tend to focus on the declarative knowledge associated with a particular discipline, and the related procedural knowledge required in its application. Beyond the capacity to apply discipline specific competences, increasing complexity in design problems now requires the creative ability to acquire broader, more diversified perspectives (Park, 2009). This has prompted debate within design education around how to effectively respond to changing industrial, societal and contextual requirements. For example, Norman (2010) and Norman and Klemmer (2014) suggest the necessity for interdisciplinary strategies aimed at the convergence of skills and knowledge are reaching critical importance if design education is to keep pace with increasingly rapid change. 
Discourse around the nature and importance of interdisciplinary learning in design has also been accompanied by studies on the effectiveness of the approach in terms the student learning experience. For example, Lee (2014) indicates the importance of preparation and increased effort as a required foundation for interdisciplinary learning, suggesting that learning effectiveness appears more sensitive to failure in an interdisciplinary context compared to conventional, discipline specific design education. On the other hand, Lattuca, Voight and Fath (2004) indicate limitations in current understanding of how interdisciplinary pedagogic strategies influence student learning experiences. Through a literature review of learning theory, Lattuca et al (ibid) question the effectiveness of previous studies, claiming the importance of interdisciplinarity to question if gains in student knowledge and skills are attributable to the interdisciplinary nature of courses? Their analysis indicated successful student learning is achieved when a combination of interdisciplinary course curricula and intentional pedagogy is used as bridge between various disciplinary perspectives.

Self and Baek (2016) indicate how an interdisciplinary team teaching approach may, in fact, negatively influence student learning. Within the team teaching condition, students described a more fragmented learning experience. This appeared to be the result of limitations in the integration of disciplinary knowledge within the curriculum. Moreover, instruction was provided by faculty from different disciplines (industrial design, mechanical engineering, ergonomic engineering) at different times, resulting in a juxtaposition of disciplinary views and ideas. Conclusions indicate the necessity of careful planning, execution and monitoring in the team teaching approach as catalyst for productive interdisciplinary learning. These existing studies indicate that, while interdisciplinarity in design education is desirable given the increasingly complex problems designers now engage, such endeavours also present complex challenges.

\section{Methods}

\section{Interview Study}

To investigate interdisciplinary approaches to undergraduate design education, and implications for the student learning experience, a series of in-depth student interviews were conducted across the DHE (School of Design \& Human Engineering, UNIST) and LDS (Loughborough Design School, Loughborough University). The following sections describe sampling approach, including participant programmes of study, interview question design, interview locations, process, timing and data analysis.

\section{Sample Groups}

Two samples were taken from the authors' home institutions (LDS \& DHE). For the LDS sample, students were identified for interview from a cohort enrolled on three undergraduate degree programmes (Table 2). A sample of $D H E$ students was taken from the single undergraduate 
programme. All participants were enrolled full-time on their respective programmes of study and were final year students between the ages of 22-29.

Table 2 Sample groups' attributes

\begin{tabular}{lcc}
\hline \multicolumn{1}{c}{ Attributes } & LDS Group & DHE Group \\
\hline No. of Participants & $\mathrm{n}=19$. & $\mathrm{n}=15$. \\
\hline Programmes of Study & - BSc Product Design \& Technology & - BSc Industrial Design \\
\hline Mode of Study & BSc Design Ergonomics & Full-time \\
\hline Year of Study & Full-time & Year 4 (of 4) \\
\hline
\end{tabular}

In the case of the LDS sample, calls for participation were sent through an online participation platform. At the $D H E$, posters were displayed around campus to advertise the study.

\section{Interview Design}

Interview questions were designed to explore student attitudes towards and experience of interdisciplinary teaching and learning. In this we attempted to understand to what extent the interdisciplinary approaches taken at the two participating institutions provided opportunities for both enhanced interdisciplinary learning and an improved student learning experience. To achieve this, the seven criteria for assessing interdisciplinarity (Table 1, C01.-C07.) were used as the bases for a set of seven open-ended interview questions (Table 3).

Table 3 Student interview questions

\begin{tabular}{|c|c|c|}
\hline Code & Interview Questions & $\begin{array}{l}\text { Criteria for } \\
\text { Interdisciplinarity }\end{array}$ \\
\hline$Q .01$ & $\begin{array}{l}\text { Thinking about your project works, talk about the influence of engineering } \\
\text { knowledge \& skills in defining the design problem }(s) ?\end{array}$ & $\begin{array}{l}\text { C01 (Awareness of } \\
\text { Disciplinarity) }\end{array}$ \\
\hline$Q .02$ & $\begin{array}{l}\text { Please discuss the role of design (approaches, methods, strategies, tools) in } \\
\text { understanding the problem }(s) \text { you addressed? }\end{array}$ & $\begin{array}{l}\text { C01 (Awareness of } \\
\text { Disciplinarity) }\end{array}$ \\
\hline \multirow{3}{*}{ Q03. } & \multirow{3}{*}{$\begin{array}{l}\text { Thinking about the design-focused courses and engineering-orientated } \\
\text { ones, please discuss the differences in your learning experience } \\
\text { (approaches, conflicts, similarities, issues, opportunities)? }\end{array}$} & $\begin{array}{c}\text { C02 (Appreciation of } \\
\text { Disciplinary Perspectives) }\end{array}$ \\
\hline & & $\begin{array}{c}\mathbf{C 0 3}(\text { Recognition of } \\
\text { Disciplinary Limitations) }\end{array}$ \\
\hline & & $\begin{array}{c}\mathrm{C05} \text { (Finding Common } \\
\text { Ground) }\end{array}$ \\
\hline \multirow{4}{*}{$Q .04$} & \multirow{4}{*}{$\begin{array}{l}\text { Thinking about your design project works, how have you reconciled and/or } \\
\text { synthesised disciplinary knowledge and understanding? }\end{array}$} & $\begin{array}{c}\text { C03 (Recognition of } \\
\text { Disciplinary Limitations) }\end{array}$ \\
\hline & & $\begin{array}{c}\text { C04 (Appropriateness of } \\
\text { Interdisciplinarity) }\end{array}$ \\
\hline & & $\begin{array}{l}\text { C05 (Finding Common } \\
\text { Ground) }\end{array}$ \\
\hline & & C07 (Integrative Skill) \\
\hline
\end{tabular}




\begin{tabular}{|c|c|c|}
\hline \multirow{2}{*}{$Q .05$} & \multirow{2}{*}{$\begin{array}{l}\text { What role did engineering skills and knowledge, the materials, electronics } \\
\text { mechanical, having evaluating the appropriateness of your design } \\
\text { solutions? }\end{array}$} & $\begin{array}{c}\text { C02 (Appreciation of } \\
\text { Disciplinary Perspectives) }\end{array}$ \\
\hline & & $\begin{array}{l}\text { C04 (Appropriateness of } \\
\text { Interdisciplinarity) }\end{array}$ \\
\hline \multirow{3}{*}{$Q .06$} & \multirow{3}{*}{$\begin{array}{l}\text { Reflecting upon your programme of study (degree course), how has the } \\
\text { integration of the different disciplines (design, engineering) influenced } \\
\text { your learning experience? }\end{array}$} & $\begin{array}{c}\text { C02 (Appreciation of } \\
\text { Disciplinary Perspectives) }\end{array}$ \\
\hline & & $\begin{array}{c}\mathbf{C 0 3} \text { (Recognition of } \\
\text { Disciplinary Limitations) }\end{array}$ \\
\hline & & C06 (Reflexivity) \\
\hline \multirow{2}{*}{$Q .07$} & \multirow{2}{*}{ Is an interdisciplinary approach of value to you in your future career? } & C06 (Reflexivity) \\
\hline & & C07 (Integrative Skill) \\
\hline
\end{tabular}

Table 3 indicates the wording of each of the seven questions, together with their relation to the criteria for assessing interdisciplinary learning (see Table 1). The seven questions were fielded in the order shown in Table 3. Student interviewees were provided with sufficient time in which to respond at their own pace. Prompts, extra clarification and follow-up questions were provided by the interviewer as part of the semi-structured interview approach.

\section{Interview Process}

Each of the 34 interview sessions lasted between 18 and 39 minutes. This generated 12.5 hours of interview recordings. At the start of each session, participants were instructed on the aims of the study. They were then provided an institutionally approved informed consent form. After preliminary questions to establish their credentials as full-time undergraduate students studying on one of the programmes presented in Table 2, the seven interview questions were presented in order (Table 3 ). At the end of the interview, subjects were asked if they had any questions of their own. They were then thanked for their time and the interview session closed.

\section{Method of Analysis}

The 12.5 hours of interview recording were transcribed after which all interviewee verbatim (questions, follow-up questions and comments) was removed in preparation for a frequency analysis. Using a grounded approach to qualitative content analysis, a first sweep of the data-set was made to generate the main dimensions of an encoding frame. This resulted in the identification of four broad categories (Table 4, D-01 AQUISITION OF INTERDISCIPLINARY KNOWLEDGE, D-02 STUDENT ATTITUDE \& INTERDISCIPLINARITY, D-03 INSTITUTION \& INTERDISCIPLINARITY, D-04 EDUCATION \& INTERDISCIPLINARITY). Following this, an analysis of the raw interview data was conducted and segmented transcriptions encoded through the four main encoding dimensions. This resulted in 423 units of thematic encoding across the four main categories.

To further analyse data within each of the four main dimensions, encoded responses were analysed again, resulting in the identification of 10 sub-categories (Table 4). Data within each of the four main dimensions was then encoded through the application of the 10 sub-categories (Table 4, D-01a-D- 
04b). To check inter-coder reliability, including validity of the encoding frame, a research assistant encoding $10 \%$ of the interview data. Results were then qualitatively checked for inter-coder reliability. No significant differences were identified between encoding.

Following the encoding of interview data through the grounded encoding frame, responses within each of the 10 sub-categories were subjected to further analysis through a cycle of In Vivo encoding (Saldana, 2013). This approach was employed as means to further analyse qualitative responses in terms of the participants own voice thereby indicating how the 10 conceptual sub-categories related to the students' own experiences.

\section{Results}

Table 4 indicates absolute frequencies of encoding $(f)$ across the four main dimensions of the encoding frame ( $D$-01 to $D-04)$, and encoding across the 10 sub-categories derived from the four dimensions ( $D$-01a to D-01c, D-02a to D-02c, D-03a to D-03b, D-04a to D-04b).

Table 4 Frequencies of encoding $(f)$ across encoding frame

\begin{tabular}{|c|c|c|}
\hline Encoding Dimension & Encoding Sub-category & $\begin{array}{l}\text { Frequency of } \\
\text { Encoding }(f)\end{array}$ \\
\hline \multirow{3}{*}{$\begin{array}{l}\text { D-01 ACQUISITION OF } \\
\text { INTERDISCIPLINARY } \\
\text { KNOWLEDGE }\end{array}$} & D-01a. Awareness of disciplinary perspectives & 55 \\
\hline & D-01b. Synthesis of disciplinary perspectives & 53 \\
\hline & D-01c. Application Catalyst for Interdisciplinary Learning & 47 \\
\hline \multicolumn{2}{|l|}{ Total } & 155 \\
\hline \multirow{3}{*}{$\begin{array}{l}\text { D-02 STUDENT } \\
\text { ATTITUDE \& } \\
\text { INTERDISCIPLINARITY }\end{array}$} & D-02a. Conflicting Disciplinary Perspectives & 59 \\
\hline & D-02b. Student Interest Driver for Interdisciplinary Interest & 25 \\
\hline & D-02c. Disciplinary Hierarchy & 22 \\
\hline \multicolumn{2}{|l|}{ Total } & 106 \\
\hline \multirow{2}{*}{$\begin{array}{l}\text { D-03 INSTITUTION \& } \\
\text { INTERDISCIPLINARITY }\end{array}$} & $\begin{array}{l}\text { D-03a. Disciplinary Perspectives Implications for Educational } \\
\text { Experience }\end{array}$ & 45 \\
\hline & D-03b. Education Provision \& Influence on Disciplinary Bias & 39 \\
\hline \multicolumn{2}{|l|}{ Total } & 84 \\
\hline \multirow{2}{*}{$\begin{array}{l}\text { D-04 EDUCATION \& } \\
\text { INTERDISCIPLINARITY }\end{array}$} & D-04a. Relevance of Interdisciplinary Education & 58 \\
\hline & $\begin{array}{l}\text { D-04b. Challenge of Application of Interdisiplinarity in } \\
\text { Student Work }\end{array}$ & 20 \\
\hline \multicolumn{2}{|l|}{ Total } & 78 \\
\hline \multicolumn{3}{|c|}{$\begin{array}{l}\text { As indicated in Table } 4 \text {, the encoding dimension } D \text {-01 (Acquisition of Interdisciplinary Knowledge) } \\
\text { received the greatest absolute frequency of encoding }(f=155) \text { followed by Student Attitudes \& } \\
\text { Interdisciplinarity }(D-02, f=106) \text {, Institution \& Interdisciplinarity }(D-03, f=84) \text { and Education \& }\end{array}$} \\
\hline
\end{tabular}


Within D-01, three sub-categories received similar frequencies of encoding: D-01a. (Awareness of Disciplinary Perspectives, $f=55$ ), D-01b. (Synthesis of Disciplinary Perspectives, $f=53$ ) and D-01c. (Application Catalyst for Interdisciplinary Learning, $f=47$ ). Examining the frequency analysis, both awareness and synthesis of interdisciplinary perspectives were equally discussed by the student participants in describing acquisition of disciplinary knowledge. Moreover, the sub-category D-01c indicated the importance of application as a driver for interdisciplinary learning $(f=47)$.

Encoding dimension D-02 (Student Attitudes \& Interdisciplinarity) emerged as the second most frequently used encoding dimension (Table 4, $f=106$ ), with three further sub-categories (D02a., Conflicting Disciplinary Perspectives; D02b., Student Interest Driver for Interdisciplinary Interest; D02c., Disciplinary Hierarchy). In terms of encoding within the D-02a sub-category (Conflicting Disciplinary Perspectives), results indicated that the disciplinary perspectives experienced as part of an interdisciplinary education were in conflict with one another. In contrast, sub-category $D-02 b$ (Student Interest Driver for Interdisciplinary Interest) was used at an encoding frequency of approximately half that of $D-02 a(f=25)$. While student interests appeared to be represented within the data as influence upon the interdisciplinary leaning experience, this was not so prevalently discussed when compared with the attitudes towards disciplinary conflicts $(D 02 a, f=59)$. Likewise, an identified tendency to stack disciplinary approaches as more or less important to their educational experience (D02c. Disciplinary Hierarchy, $f=22$ ) was less prevalent within the data compared to perception of tensions within disciplinary perspectives.

Encoding dimension D-03 (Institution \& Interdisciplinarity, $f=84$ ) indicated the students' discussion of institutional context as influence upon an interdisciplinary education. Within this main dimension, the sub-categories D03a (Disciplinary Perspectives Implications for Educational Experience, $f=45$ ) and D03b (Education Provision \& Influence on Disciplinary Bias, $f=39$ ) were identified. In terms of D03a, encoding indicated how instructors' (or tutors within UK institutions) own disciplinary orientations implicated the students' biasing towards one discipline over another. Likewise, encoding identified the provision of courses and programmes as potentially compounding the biasing of disciplinary perspectives (D03b. Education Provision \& Influence on Disciplinary Bias, $f=39$ ).

Finally, encoding through the frame's fourth dimension (D-04 Education \& Interdisciplinarity, $f=78$ ) indicated student discussion of both the relevance of an interdisciplinary education (D04a. Relevance of Interdisciplinary Education, $f=58$ ) and, to a lesser extent, the challenge in application of interdisciplinary knowledge in their own project works (D04b. Challenge of Application of Interdisiplinarity in Student Work, $f=20$ ). This final result thus conflicted with D-01c above (Application Catalyst for Interdisciplinary Learning, $f=47$ ).

Figure 1 graphically compares encoding across the frame's four main dimensions ( $D$-01 to D-04) between the two sample groups ( $L D S \& D H E$ ). To compare encoding across interviews of varying durations, encoding is illustrated as mean percentage frequencies ( $M f \%)$. 


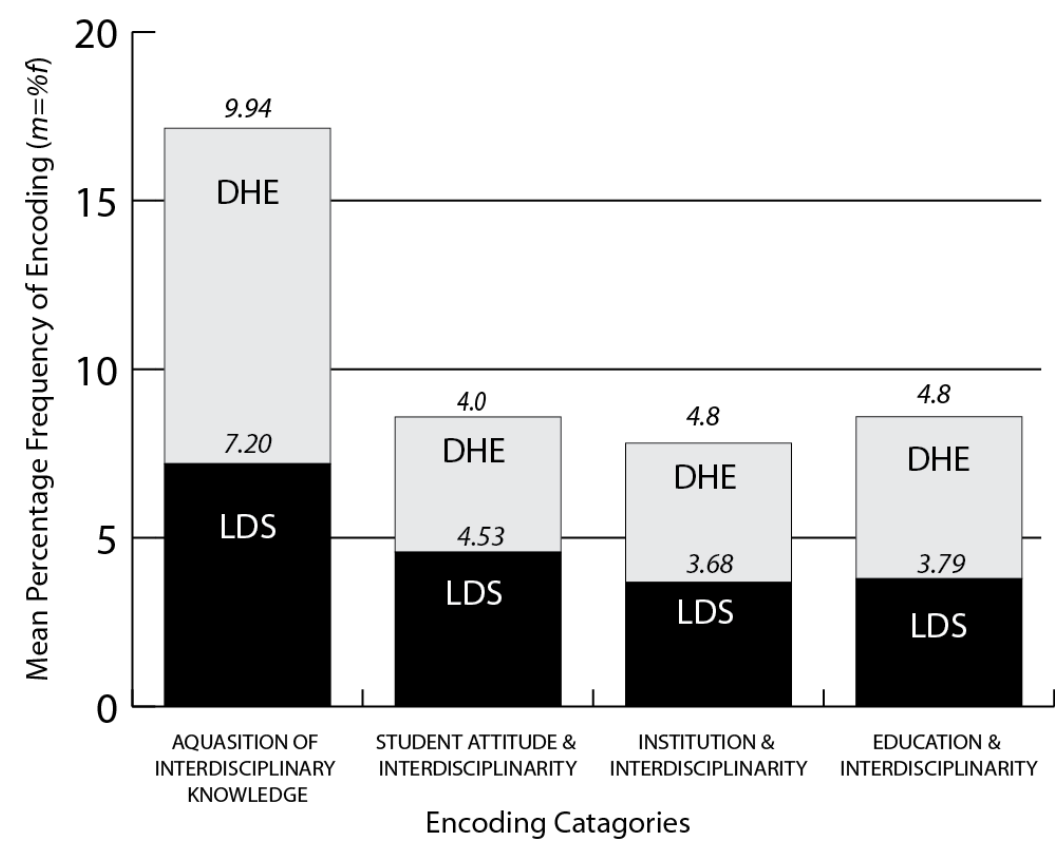

Fig. 1 Comparison of encoding between two sample groups ( $L D S \& D H E)$

As indicated in Figure 1, differences were identified in frequencies (\%f) with which responses were encoded across the four encoding dimensions (D-01-D-04) and between the two sample groups ( $L D S$ \& DHE). For example, for the most frequently used encoding category (D-01. Acquisition of Interdisciplinary Knowledge, $f=155$ ) the mean percentage frequency for $D H E$ respondents was recorded as $(M f \%=9.94)$, compared to an $L D S$ mean encoding frequency of $(M \% f=7.2)$, indicating the DHE students were more inclined to discuss interdisciplinarity in terms knowledge acquisition compared to the $L D S$ sample.

The following sections focus on the four main encoding dimensions in a sequential order and at a finer grain of analysis, including comparisons of percentage encoding frequencies between the two sample groups ( $L D S \& D H E)$. This is supported by the presentation of results within each subcategory, together with further In Vivo analysis. However, the analysis was restricted to the seven subcategories that received an absolute encoding frequency of 40 or more (i.e. D-01a to D01c, D-02a \& D02b, D-03a and D-04a).

\section{D-01 AQUISITION OF INTERDISCIPLINARY KNOWLEDGE}

\section{D-01a. Awareness of Disciplinary Perspectives}

$D$-01a was the most often used sub-category in the encoding of student responses across the frame's four dimensions $(f=55)$. Figure 2 illustrates percentage encoding frequencies (\%f) for the sub-category $D-01 a$ across the two sample groups. 


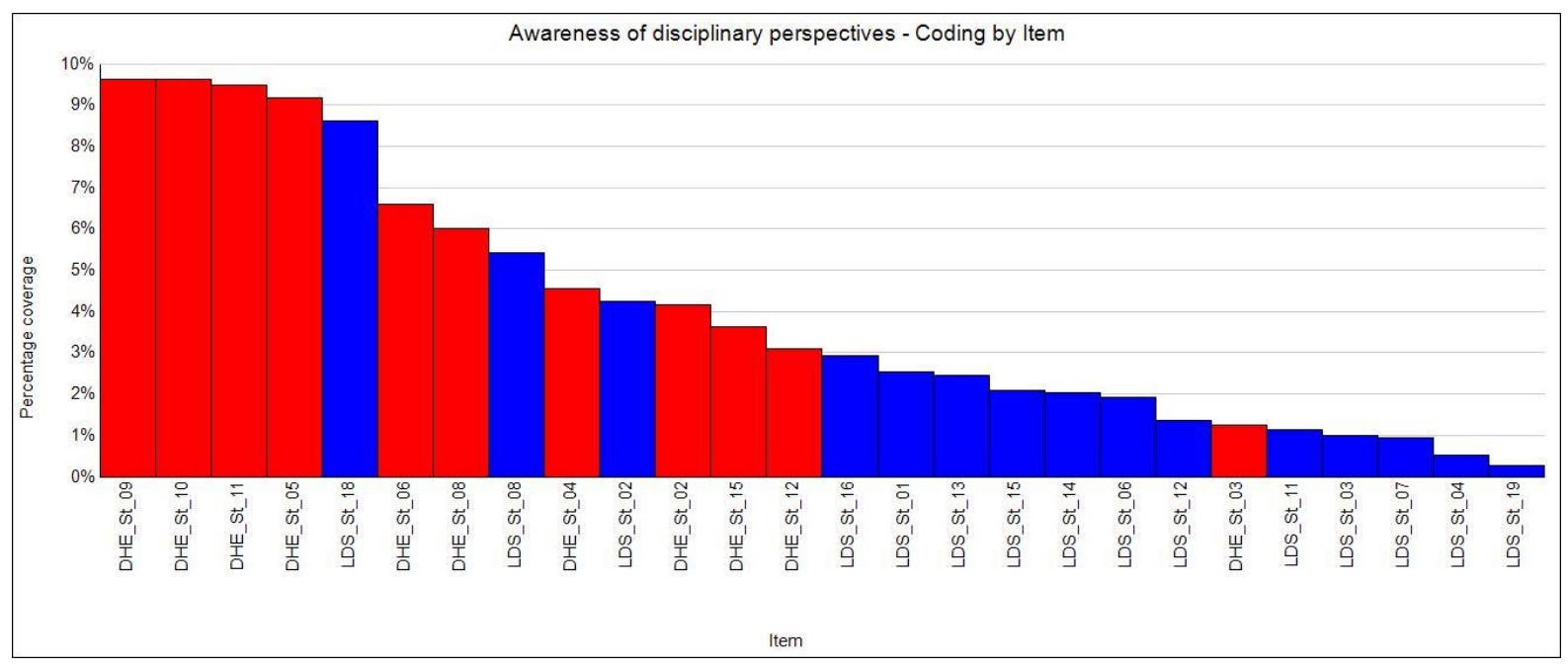

Fig. 2 Sub-category D-01a percentage encoding frequencies (\%f)

As indicated in Figure 2, the four highest frequencies of encoding were recorded for four $D H E$ students (DHE_St_09, DHE_St_10, DHE_St_11,DHE_st_05). This indicated DHE students were inclined to indicate an awareness of different disciplinary perspectives more frequently than their $L D S$ counterparts. Table 5 presents a sample of In Vivo encoding within sub-category D-01a.

Table 5 In Vivo encoding of sub-category $D-01 a$

\begin{tabular}{|c|c|c|}
\hline Stud. & D-01a Awareness of Disciplinary perspectives & In Vivo Encoding \\
\hline \multirow{3}{*}{$\begin{array}{l}\text { DHE } \\
\text { St_09 }\end{array}$} & $\begin{array}{l}\text { Perception is }{ }^{I} \text { quite different of the one problem. They sometimes see the } \\
\text { same problem but they see it with a quite different eye, so the engineers see } \\
\text { some data, their problems are full of data and some industrial designers } \\
\text { thinking is quite different. }\end{array}$ & $\begin{array}{l}\text { 1.quite different of the one } \\
\text { problem }\end{array}$ \\
\hline & $\begin{array}{l}\text { It is kind of a two eyes thing, a kind of }{ }^{2} \text { industrial eye and kind of ergonomics } \\
\text { eye. }\end{array}$ & $\begin{array}{l}\text { 2.industrial eye and kind of } \\
\text { ergonomics eye }\end{array}$ \\
\hline & $\begin{array}{l}\text { I think they are }{ }^{3} \text { different in language, industrial designers don't have any } \\
\text { language about engineering, and the engineers don't have any language } \\
\text { about industrial design. }\end{array}$ & 3.different in language \\
\hline \multirow{2}{*}{$\begin{array}{l}\text { DHE } \\
\text { St_10 }\end{array}$} & \multirow{2}{*}{$\begin{array}{l}\text { Design is quite, I mean, I think there is }{ }^{4} \text { no specific way or justification yet } \\
\text { but ergonomics needs more calculation and }{ }^{5} \text { specific relationships between } \\
\text { the cause and effect. }\end{array}$} & 4.no specific way \\
\hline & & 5.specific relationships \\
\hline \multirow{4}{*}{$\begin{array}{l}\text { DHE } \\
\text { St_05 }\end{array}$} & $\begin{array}{l}{ }^{6} \text { identify the problems in different ways than design maybe, so they want to } \\
\text { see problems in kind of quantified ways. }\end{array}$ & $\begin{array}{l}\text { 6.identify the problems in } \\
\text { different }\end{array}$ \\
\hline & \multirow{2}{*}{$\begin{array}{l}\text { design is what you can }{ }^{7} \text { see like right there, so we try to make the }{ }^{8} \text { outcome } \\
\text { look as satisfying as possible from a design perspective because that is what } \\
\text { people will evaluate. }\end{array}$} & 7.see like right there \\
\hline & & 8.outcome look as satisfying \\
\hline & $\begin{array}{l}\text { adding engineering into design actually makes the product pretty and like in } \\
\text { a nutshell }{ }^{9} \text { pretty and useful. }\end{array}$ & 9.pretty and useful \\
\hline $\begin{array}{l}\text { DHE } \\
\text { St_06 }\end{array}$ & $\begin{array}{l}\text { Most design students for example, other design schools, don't know how to } \\
{ }^{10} \text { make this product and what the material is. }\end{array}$ & 10.make this product \\
\hline \multirow{3}{*}{$\begin{array}{l}L D S \\
S t \_18\end{array}$} & $\begin{array}{l}\text { When I think of engineering I think }{ }^{11} \text { engineering is solving clearly defined } \\
\text { problems, so how do I unite this thing, more or less. Whereas }{ }^{12} \text { design } \\
\text { problems are always more complex I think and that so it's not an obvious } \\
\text { solution. }\end{array}$ & $\begin{array}{l}\text { 11.engineering is solving } \\
\text { clearly defined problems }\end{array}$ \\
\hline & $\begin{array}{l}\text { When }{ }^{13} \text { the problem becomes more defined, when you start working out what } \\
\text { it is you actually need and then the engineering comes in. }\end{array}$ & more complex \\
\hline & $\begin{array}{l}\text { By electronics it's quite sort of in a box, it's you know, }{ }^{14} \text { all the information } \\
\text { you need is out there and in a kind of }{ }^{15} \text { clearly defined way. }\end{array}$ & $\begin{array}{l}\text { 13.the problem becomes more } \\
\text { defined }\end{array}$ \\
\hline
\end{tabular}




\begin{tabular}{|c|c|c|}
\hline & $\begin{array}{l}{ }^{16} \text { good constraint I really like that kind of constraint. Yeah, because without } \\
\text { those then the idea is going to be. }\end{array}$ & $\begin{array}{l}\text { 14.all the information you need } \\
\text { 15.clearly defined way } \\
\text { 16.good constraint }\end{array}$ \\
\hline $\begin{array}{l}\text { LDS } \\
\text { St_08 }\end{array}$ & $\begin{array}{l}\text { Designer as, I often come up with a million ideas, pre-course won't work. If } \\
\text { I've designed something for engineering, everything }{ }^{17} \text { will work but the form } \\
\text { maybe limited. } \\
\text { Designed could be }{ }^{18} \text { anything you wanted, so that's why that this is you } \\
\text { design a shape then work to your engineering knowledge to refine that } \\
\text { shape. }\end{array}$ & $\begin{array}{l}\text { 15.will work but the form } \\
\text { maybe limited } \\
\text { 16.anything you wanted }\end{array}$ \\
\hline $\begin{array}{l}\text { LDS } \\
\text { St_02 }\end{array}$ & $\begin{array}{l}\text { potential manufacturer and }{ }^{19} \text { discussing the issues with the undercuts and } \\
\text { how it's actually manufactured and then taking back the design and kind of } \\
\text { changing it to suit. } \\
\text { If I'm creating concepts I can }{ }^{20} \text { actually explain it to an engineer to a certain } \\
\text { level. }\end{array}$ & $\begin{array}{l}\text { 17.discussing the issues } \\
\text { 18.actually explain it to an } \\
\text { engineer }\end{array}$ \\
\hline $\begin{array}{l}L D S \\
S t \_16\end{array}$ & $\begin{array}{l}\text { Able to }{ }^{21} \text { sit down with engineers and propose a design preposition. } \\
\text { Proposition sorry, that will be accepted by them without having to go } \\
\text { backwards and forwards. } \\
\text { Doing something with microelectronics }{ }^{22} \text { you can work out whether you can } \\
\text { actually program it or not. } \\
\text { Ergonomics }{ }^{23} \text { aren't usually such a structural problem in terms of } \\
\text { manufacture and things as the electronics and mechanics stuff. }\end{array}$ & $\begin{array}{l}\text { 19.sit down with engineers } \\
\text { 20.you can work out } \\
\text { 21.aren't usually such a } \\
\text { structural problem }\end{array}$ \\
\hline
\end{tabular}

As indicated in Table 5, students appeared to indicate awareness in terms differences in how engineering and design may relate to practical project requirements. For example, DHE_St_09 discussed the ways in which design and engineering may see the same problem in different ways, 'They sometimes see the same problem but they see it with a quite different eye, so the engineers see some data, their problems are full of data and some industrial designers thinking is quite different' (Table 5). DHE_St_09 also spoke of the languages used by different disciplines, leading to reflections on communication between disciplines, 'they are ${ }^{3}$ different in language, industrial designers don't have any language about engineering, and the engineers don't have any language about industrial design'. However, LDS_St_02 saw their education as providing opportunities for bridge-building between disciplinary perspectives, (Table $5,{ }^{20}$ actually explain it to an engineer), indicating awareness of communicational challenges between disciplines, and the opportunities of an interdisciplinary education therein. DHE_St_05 indicated awareness of the potential value of different disciplinary knowledge in terms new product development, 'adding engineering into design actually makes the product pretty and like in a nutshell ${ }^{9}$ pretty and useful'. Likewise, LDS_St_O1 exhibited awareness of how disciplinary perspectives may contribute to underpinned design ideation through the application of both design and engineering knowledge, achieving a required functionality.

The frequency and In Vivo analysis indicated awareness of disciplinary perspectives, from communication to problem definition and solution ideation. However, differing encoding frequencies between the $D H E$ and $L D S$ groups may have indicated awareness was not equally distributed between the two institutions and across individual students.

\section{D-01b. Synthesis of Disciplinary Perspectives}


The sub-category $D$-01b. $(f=53)$ indicated instances where participants discussed the extent to which they reconciled disciplinary perspectives for the benefit of their own educational experiences. In this respect, discussion went further than awareness to indicate a more critical and applicable acquisition of disciplinary knowledge and skills. As indicated in Figure 3, encoding within D-01b. attracted a percentage frequency range of 2 to 12 percent $(\% f=12-2 \%)$.

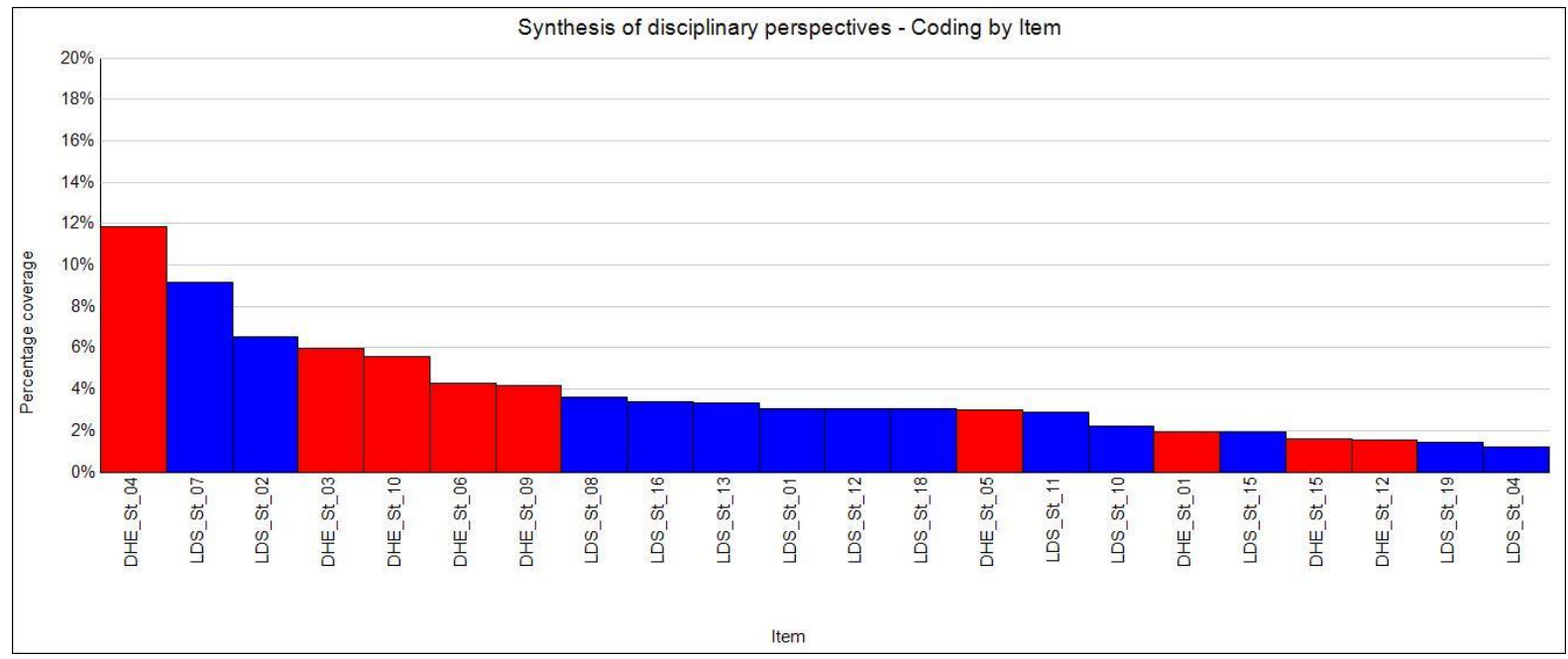

Fig. 3 Percentage encoding frequencies (\%f) for $D-01 b$

Results indicated variation in the amount of time participants discussed the synthesis of disciplinary approaches. This may have indicated that some students found it more challenging to synthesis disciplinary skills and knowledge than others or, at the least, to articulate how and by what means they achieved an integration of the disciplines to the benefit of their own education. As above, response data encoded as $D$-01b. was subjected to further analysis through In Vivo encoding (Table 6).

Table 6 In Vivo encoding of sub-category $D-01 b$

\begin{tabular}{|c|c|c|}
\hline Code & D01b. Encoded Conversation: Synthesis of Disciplinary Perspectives & In Vivo Coding \\
\hline$D H E$ & $\begin{array}{l}\text { Come new idea because I always think about the engineering part, so why some } \\
{ }^{1} \text { creative idea is deleted by some engineering thinking. }\end{array}$ & $\begin{array}{l}\text { 1.creative idea is deleted } \\
\text { by some engineering }\end{array}$ \\
\hline St_04 & $\begin{array}{l}\text { the kind of }{ }^{2} \text { problem may need just a little change; but some creative designer will } \\
\text { be thinking about the contact lens. }\end{array}$ & $\begin{array}{l}\text { 2.problem may need just } \\
\text { a little change }\end{array}$ \\
\hline $\begin{array}{l}\text { DHE } \\
\text { St_03 }\end{array}$ & $\begin{array}{l}\text { to design, people already design experiment for what we need for the first topic. I } \\
{ }^{3} \text { used the design case to catch what history of problem is. }\end{array}$ & $\begin{array}{l}\text { 3.used the design case to } \\
\text { catch }\end{array}$ \\
\hline $\begin{array}{l}\text { DHE } \\
S t \_10\end{array}$ & $\begin{array}{l}\text { But they }{ }^{4} \text { needed to know that the intellectual disability people's hand is not that } \\
\text { developed. So, they are not able to touch or sense more specifically, so kind of } \\
\text { chopsticks for, so that's kind of }{ }^{5} \text { knowledge versus needs when they evaluate. }\end{array}$ & $\begin{array}{l}\text { 4.needed to know } \\
\text { 5.knowledge versus needs }\end{array}$ \\
\hline $\begin{array}{l}\text { DHE } \\
\text { St_06 }\end{array}$ & $\begin{array}{l}\text { If I have just only }{ }^{6} \text { one background I could not make this souvenir because this } \\
\text { souvenir has magnetic and smart phone }{ }^{7} \text { application together to use how to } \\
\text { assemble this souvenir. }\end{array}$ & $\begin{array}{l}\text { 6.one background I could } \\
\text { not make } \\
\text { 7.application together }\end{array}$ \\
\hline $\begin{array}{l}\text { LDS } \\
\text { St_07 }\end{array}$ & $\begin{array}{l}\text { A little bit more to it so I can }{ }^{8} \text { delve deeper into materials and manufacturing and } \\
\text { things like that. } \\
I^{9} \text { try to balance sort of the interaction and the user experience with the actual } \\
\text { product. }\end{array}$ & $\begin{array}{l}\text { 8.delve deeper into } \\
\text { 9.try to balance }\end{array}$ \\
\hline
\end{tabular}




\begin{tabular}{|c|c|c|}
\hline & $\begin{array}{l}{ }^{10} \text { look at things more from, I think, a technical point of view and then I sort of, I } \\
\text { might choose materials and things before I sort of decided that what's it's going to } \\
\text { look maybe because of their purposes or their properties. } \\
\text { I think it's }{ }^{11} \text { about balancing sort of the best both worlds depending on where the } \\
\text { target market or the target user is based. } \\
\text { Manufacturing knowledge, really good fabrication skills and they were sort of } \\
{ }^{12} \text { filling the roles of an architect, of a fabricator as a tool maker. So, I definitely } \\
\text { think there is a }{ }^{13} \text { wide aspect of opportunity. }\end{array}$ & $\begin{array}{l}\text { 11.about balancing sort of } \\
\text { the best both worlds } \\
\text { 12.filling the roles } \\
\text { 13. wide aspect of } \\
\text { opportunity }\end{array}$ \\
\hline \multirow{3}{*}{$\begin{array}{l}\text { LDS } \\
\text { St_02 }\end{array}$} & $\begin{array}{l}\text { Ergonomic based }{ }^{14} \text { looking at different tools that are currently on the market, } \\
\text { different hand positions to a few children's hand size using. }\end{array}$ & 14.looking at different \\
\hline & $\begin{array}{l}\text { Is it manufacturable? And then you cut it up and gently flow it, yeah, so that was } \\
\text { kind of engineering based learning how within cut you inject flow rates and }{ }^{15} \text { how } \\
\text { it actually might be manufactured and }{ }^{16} \text { any of the issues there. }\end{array}$ & $\begin{array}{l}\text { 15.how it actually might } \\
\text { be }\end{array}$ \\
\hline & $\begin{array}{l}\text { Constraint but it's a }{ }^{17} \text { needed constraint to produce a product to actually get } \\
\text { manufactured. }\end{array}$ & 17.needed constraint \\
\hline $\begin{array}{l}\text { LDS } \\
\text { St_08 }\end{array}$ & $\begin{array}{l}\text { Mechanically it's more about, }{ }^{18} \text { what I look into is if someone drops it because I'm } \\
\text { not designing bridges so it's case of basic if I drop it will it break. }\end{array}$ & 18.what I look into \\
\hline \multirow{2}{*}{$\begin{array}{l}L D S \\
S t \_16\end{array}$} & $\begin{array}{l}{ }^{19} \text { requires a lot of skills and knowledge about motor consistencies and I want to } \\
\text { create something that basically removes the skilled labour aspect and also sort of } \\
\text { reduce the time taken. }\end{array}$ & $\begin{array}{l}\text { 19.requires a lot of skills } \\
\text { and knowledge } \\
\text { 20.I know what }\end{array}$ \\
\hline & $\begin{array}{l}{ }^{20} \text { I know what thicknesses these materials have to be, what kind of materials to use } \\
\text { and it }{ }^{21} \text { saves you a lot of headaches in the future. }\end{array}$ & $\begin{array}{l}\text { 21.saves you a lot of } \\
\text { headaches }\end{array}$ \\
\hline
\end{tabular}

Participant DHE_St_O6 discussed understanding of the problem from various perspectives as a means of positively informing their design work, '7 application together' (Table 6). Likewise, DHE_St_10 discussed how both the needs of the user and knowledge of what may be possible informed their project work to provide opportunities for more thoughtful solutions. LDS_St_07 spoke of an ability to understand the problem from a deeper, interdisciplinary perspective to the benefit of particular requirements related to material and manufacturing, speaking of both a balancing between disciplines, "Il about balancing sort of the best both worlds' (Table 6) and the greater opportunities provided through an interdisciplinary approach, ' ${ }^{13}$ wide aspect of opportunity'. While $L D S \_S t \_16$ spoke of how knowledge of engineering proved useful in understanding the potential of design ideas in relation to engineering constraints, ' ${ }^{20} I$ know what'. LDS_St_O2 indicated the necessity of engineering constraints to provide opportunity for more realistic solutions, 'but it's a ${ }^{17}$ needed constraint to produce a product to actually get manufactured.'

In contrast, DHE_St_04 appeared to indicate the challenges of synthesis in discussing how an engineering perspective constrained creativity, 'new idea because I always think about the engineering part, so why some ' creative idea is deleted by some engineering thinking'. The student also indicated how the engineering approach may result in incremental change compared to more radical solution ideation, 'the kind of ${ }^{2}$ problem may need just a little change; but some creative designer will be thinking about the contact lens'. Thus the In Vivo analysis indicated that, while synthesis of disciplinary knowledge appeared evident in student responses, it was also seen to have negative implications in terms creativity. 


\section{D-01c. Application Catalyst for Interdisciplinary Learning}

An interesting finding from the analysis was participant discussion of the necessity for application as means to drive interdisciplinary knowledge and skill acquisition $(D-01 c, f=47)$. Figure 4 illustrates encoding percentage frequencies (\%f).

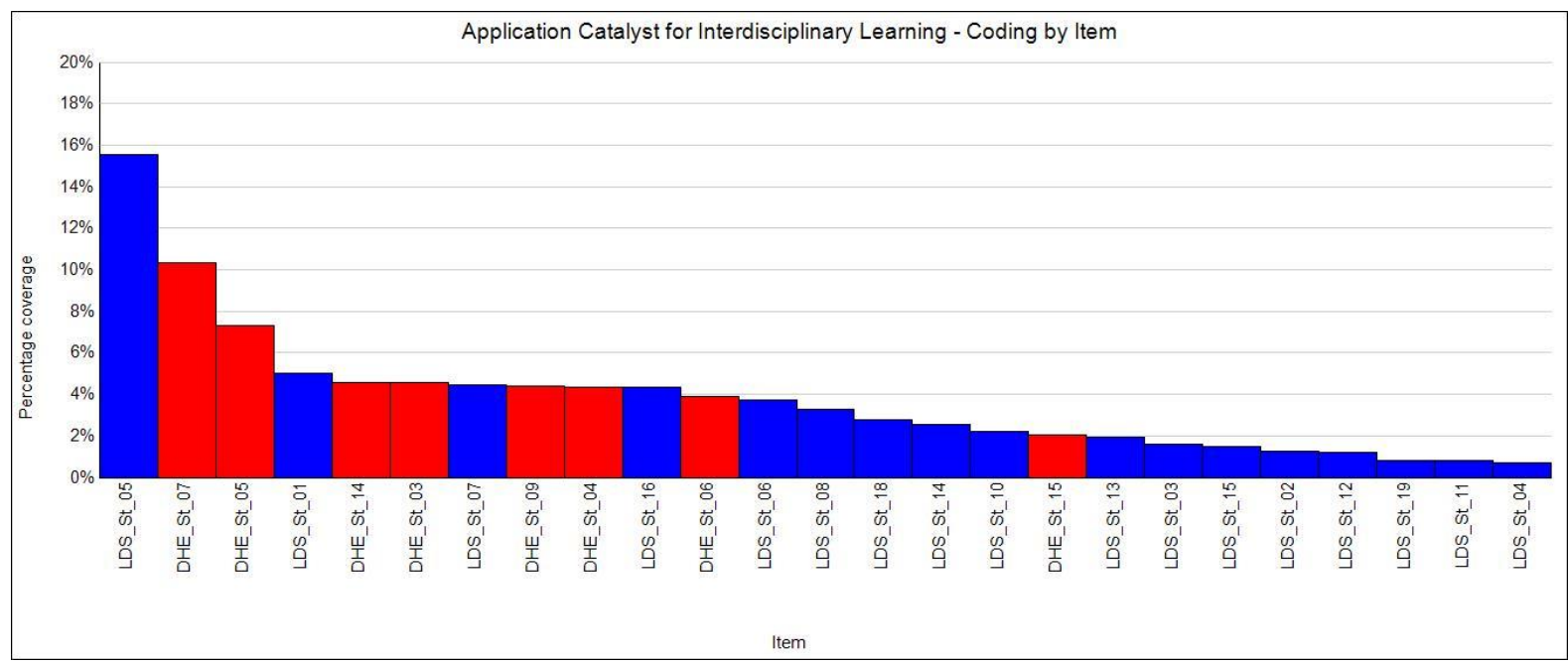

Fig. 4 Percentage encoding frequencies (\%f) for $D-01 c$

$L D S \_S t \_05$ received the highest frequency of encoded response for the sub-category $D-01 c .(\% f=15.5)$ followed by $D H E \_S t \_07(\% f=10)$ and $D H E \_S t \_05(\% f=7)$. These participants were followed by a mixed tail of encoded responses ( $L D S \_S t \_01 \% f=5$ to $\left.L D S \_S t \_04 \% f=1\right)$. If encoding frequency is indicative of the importance of application as catalyst for learning, results appeared to indicate some students were better able to leverage application as driver for interdisciplinary learning compared to others. Table 7 shows further In Vivo encoding for the sub-category.

Table 7. In Vivo encoding of D-O1c

\begin{tabular}{|c|c|c|}
\hline Code & $\begin{array}{l}\text { D-01c. Encoded Conversation: Application Catalist for } \\
\text { Interdisciplinary Learning }\end{array}$ & In Vivo Coding \\
\hline \multirow{6}{*}{$\begin{array}{l}\text { LDS } \\
\text { St_05 }\end{array}$} & $\begin{array}{l}\text { and }{ }^{l} \text { all the things you can do with engineering without just, you know, opening } \\
\text { the text on page one. }\end{array}$ & $\begin{array}{l}\text { 1. all the things you can } \\
\text { do }\end{array}$ \\
\hline & $\begin{array}{l}\text { We have }{ }^{2} \text { some great projects like the design manufacturing technology module } \\
\text { in year two is fantastic. }\end{array}$ & 2. some great projects \\
\hline & that DMT is a fauprito & 3. it's very practical \\
\hline & $\begin{array}{l}\text { that DMT is a favourite module within the course and I think it's because }{ }^{3} \text { it's } \\
\text { very practical and }{ }^{4} \text { you learn from doing. }\end{array}$ & 4. you learn from doing. \\
\hline & So, I think you actually do 5 learn a lot while you're doing it but, yeah, I mean. & $\begin{array}{l}\text { 5. learn a lot while you're } \\
\text { doing. }\end{array}$ \\
\hline & $\begin{array}{l}\text { Something like this where you design a product and the }{ }^{6} \text { first time you try an } \\
\text { injection mould and you're like, "Is it going to work? }\end{array}$ & 6. first time you try \\
\hline \multirow{2}{*}{$\begin{array}{l}\mathrm{DHE} \\
\text { St_07 }\end{array}$} & $\begin{array}{l}\text { Yes, it influenced me to think like efficiency of design method, like when I have to } \\
{ }^{7} \text { conduct research or something I try to be more efficient to work fast and more. }\end{array}$ & $\begin{array}{l}\text { 7. conduct research or } \\
\text { something I try to be more } \\
\text { efficient }\end{array}$ \\
\hline & $\begin{array}{l}\text { Determined the angle, the curvature what }{ }^{8} \text { I used was the statistical knowledge } \\
\text { and it gives the threshold, it will be this is right or not, it gives me that. }\end{array}$ & $\begin{array}{l}\text { 8. I used was the } \\
\text { statistical knowledge }\end{array}$ \\
\hline $\begin{array}{l}\text { DHE } \\
\text { St_05 }\end{array}$ & $\begin{array}{l}\text { So, I tried to talk about what kind of things that might affect your back and all } \\
\text { kinds of stuff, so }{ }^{9} \text { they actually listened to my suggestion and they agreed to not }\end{array}$ & $\begin{array}{l}\text { 9. they actually listened to } \\
\text { my }\end{array}$ \\
\hline
\end{tabular}




\begin{tabular}{|c|c|c|}
\hline & $\begin{array}{l}\text { like adjust the sizes to my suggestion but kind of make a compromise in between } \\
\text { the sizes that they wanted and I wanted. }\end{array}$ & \\
\hline $\begin{array}{l}\text { LDS } \\
\text { St_01 }\end{array}$ & $\begin{array}{l}I^{10} \text { focused on ergonomics for that, I would say because of I didn't, it needs to be } \\
\text { something that I could hold in hand. It needs to be active, it needed to be } \\
\text { something that could be on poolside } \\
\text { Positioning of the screen "needed to be at a perfect angle. That it wasn't too up } \\
\text { straight but it wasn't also lying flat that you have to like lift yourself up. }\end{array}$ & $\begin{array}{l}\text { 10. focused on } \\
\text { ergonomics for that } \\
\text { 11. needed to be at a } \\
\text { perfect }\end{array}$ \\
\hline $\begin{array}{l}\text { DHE } \\
\text { St_14 }\end{array}$ & $\begin{array}{l}\text { I can }{ }^{12} \text { use ergonomics in ID design to support my idea and when I do } \\
\text { ergonomics projects design appearance is very important also. } \\
\text { That }{ }^{13} \text { kind of course was very helpful for taking on other courses' design project } \\
\text { like we had that one. }\end{array}$ & $\begin{array}{l}\text { 12. use ergonomics in ID } \\
\text { design to support my idea } \\
\text { 13. kind of course was } \\
\text { very helpful }\end{array}$ \\
\hline $\begin{array}{l}\text { DHE } \\
\text { St_03 }\end{array}$ & $\begin{array}{l}\text { Anthropometry }{ }^{14} \text { highly influenced my focus on the project is I remember } \\
\text { because usually when the project to design the product which humans highly use } \\
\text { it should be, I thought it should be decided from an Anthropometry view. }\end{array}$ & $\begin{array}{l}\text { 14. highly influenced my } \\
\text { focus on the project. }\end{array}$ \\
\hline $\begin{array}{l}\text { LDS } \\
\text { St_07 }\end{array}$ & $\begin{array}{l}\text { It's using that a little bit further and then }{ }^{15} \text { getting to apply all, which I think is } \\
\text { very good. } \\
\text { But because I understood }{ }^{16} \text { the principle of how to apply it and how it works, I } \\
\text { could pick those equations quite quickly. }\end{array}$ & $\begin{array}{l}\text { 15. getting to apply all } \\
\text { 16. the principle of how to } \\
\text { apply it }\end{array}$ \\
\hline $\begin{array}{l}\text { DHE } \\
\text { St_O9 }\end{array}$ & $\begin{array}{l}{ }^{17} \text { any idea on how to address the users correctly at the time the ergonomics or } \\
\text { some tools or methods or strategy could help. } \\
I^{18} \text { got some video clips I watch again and checked what they did and I } \\
\text { calculated sometimes the distance of people between two users based on the } \\
\text { video. }\end{array}$ & $\begin{array}{l}\text { 17. any idea on how to } \\
\text { address the users } \\
\text { 18. got some video clips I } \\
\text { watch again }\end{array}$ \\
\hline
\end{tabular}

As indicated by $L D S \_S t$ _05, application of interdisciplinary knowledge appeared to act as catalyst for student ability to synthesis interdisciplinary skills, 'that DMT [Design for Manufacturing Technology] is a favourite module within the course and I think it's because ${ }^{3}$ it's very practical and ${ }^{4}$ you learn from doing. ' Likewise, DHE_St_07 indicated the value of application of ergonomic principles to support his design works, 'to think like efficiency of design method, like when I have to ${ }^{7}$ conduct research or something I try to be more efficient to work fast and more'. DHE_st_05 also described how application supported understanding within a team-based project assignment, indicating the contribution of ergonomics to help drive the direction of potential solutions, " ${ }^{6}$ they actually listened to my suggestion and they agreed to not like adjust the sizes to my suggestion but kind of make a compromise in between the sizes.' Likewise, DHE_st_03 indicated how the direction of design project work was facilitated through the application of ergonomic knowledge, 'Anthropometry ${ }^{14}$ highly influenced my focus on the project as I remember because usually when the project to design the product which humans highly use it should be, I thought it should be decided from an Anthropometry view'.

DHE_st_09 spoke of how acquired engineering approached appeared to support their design research, resulting in an appreciation of the value of different approaches, ${ }^{18}$ got some video clips I watch again and checked what they did and I calculated sometimes the distance of people between two users based on the video.' The encoding, frequency and further In Vivo coding indicated how application appeared to drive student appreciation of different disciplinary approaches, resulting in enhanced interdisciplinary learning experiences. In the applied discipline of design, this result may be of 
particular relevance as potential driver for interdisciplinary approaches, programmes and pedagogic endeavours.

\section{D-02. STUDENT ATTITUDE \& INTERDISCIPLINARITY}

A second main dimension of the encoding frame indicated student attitudes as implicit in the acquisition of interdisciplinary skills and knowledge. The dimension included three sub-categories: $D$ 02a. (Conflicting Disciplinary Perspectives, $f=55$ ), indicating student attitude towards conflict between disciplinary knowledge acquisition. D-02b. (Student Interests as Driver for Interdisciplinary Interests, $f=25$ ), describing how participants indicated their own interests in an interdisciplinary approach as implicating engagement with interdisciplinarity. Finally, sub-category $D-02 c$. (Disciplinary Hierarchy, $f=22$ ), indicated student ranking of disciplines as of a greater or lesser importance.

\section{D-02a. Conflicting Disciplinary Perspectives}

As illustrates in Figure 5, the frequencies with which responses were encoded differed across participants (DHE_St_07, \% f=11 to DHE_St_O2 \% $f=1$ ); of the five participants with the highest percentage frequencies of encoding, four where $D H E$, with one $L D S$.

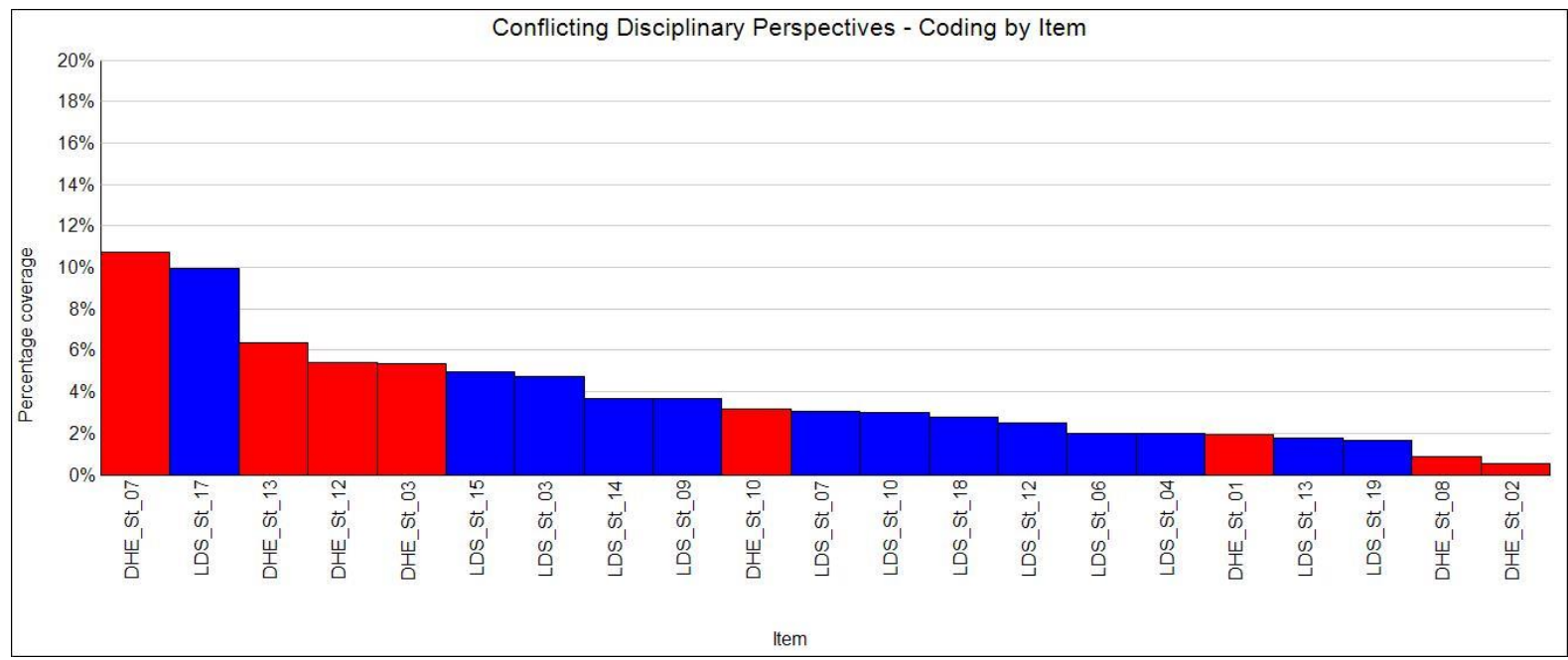

Fig. 5 Percentage encoding frequencies $(\% f)$ for $D-02 a$

As above, response data was subjected to a second round of In Vivo encoding (Table 8).

Table 8 In Vivo encoding of sub-category $D$-01a

\begin{tabular}{|c|c|c|}
\hline Stu. & D-02a. Encoded Conversation: Conflicting Disciplinary Perspectives & In Vivo code \\
\hline $\begin{array}{l}\text { DHE } \\
\text { St_07 }\end{array}$ & $\begin{array}{l}\text { Hard to cover two parts because I was more interested in design but I } \\
\text { should take some classes about I engineering which is not related to } \\
\text { design directly. Like I learned manufacturing process but it's not helpful } \\
\text { to design. So, at the time I cannot figure out }{ }^{2} \text { what is the good point of } \\
\text { integration of design and engineering. }\end{array}$ & $\begin{array}{l}\text { 1. engineering which is } \\
\text { not related to design } \\
\text { 2. what is the good } \\
\text { point of integration }\end{array}$ \\
\hline $\begin{array}{l}\text { LDS } \\
\text { St_17 }\end{array}$ & ${ }^{3}$ prohibit your design ability because I know that the design I came up & 3. Prohibit your design \\
\hline
\end{tabular}




\begin{tabular}{|c|c|c|}
\hline & $\begin{array}{l}\text { with for design manufacturing was probably one of the worst pieces of } \\
\text { design I've ever come up with. } \\
\text { it turns out to not be manufactureable then try and change the design so } \\
\text { that it is but stay true to the original design and try }{ }^{4} \text { not to completely } \\
\text { and drastically change it because of engineering. }\end{array}$ & $\begin{array}{l}\text { ability. } \\
\text { 4. not to completely } \\
\text { and drastically change } \\
\text { it because of } \\
\text { engineering. }\end{array}$ \\
\hline DHE & $\begin{array}{l}\text { Do I know anything about engineering? My response would usually be, } \\
{ }^{5} \text { No, I don't, not at all. }\end{array}$ & 5. No, I don't, not at all \\
\hline St_13 & $\begin{array}{l}\text { I would have }{ }^{6} \text { preferred to have acquired, for example, computer aided } \\
\text { design, and industrial design studies in comparison to a collection of the } \\
\text { ergonomics features. }\end{array}$ & $\begin{array}{l}\text { 6. preferred to have } \\
\text { acquired }\end{array}$ \\
\hline $\begin{array}{l}\text { DHE } \\
{ }_{2}^{\text {St_1 }}\end{array}$ & $\begin{array}{l}\text { Instruction from engineering point of view, I think the engineering } \\
\text { professors tend to see the things or evaluate the things }{ }^{7} \text { based on the } \\
\text { fixed knowledge, the fixed answer. }\end{array}$ & $\begin{array}{l}\text { 7. based on the fixed } \\
\text { knowledge }\end{array}$ \\
\hline $\begin{array}{l}\text { DHE } \\
\text { St_03 }\end{array}$ & $\begin{array}{l}\text { Students it's }{ }^{8} \text { hard to cover two parts because I was more interested in } \\
\text { design but I should take some classes about engineering which is }{ }^{9} \text { not } \\
\text { related to design directly. Like I learned manufacturing process but it's } \\
\text { not helpful to design. }\end{array}$ & $\begin{array}{l}\text { 8. hard to cover two } \\
\text { parts } \\
\text { 9. not related to design } \\
\text { directly }\end{array}$ \\
\hline
\end{tabular}

DHE_St_07 discusses the ways in which engineering and design are not well related, "engineering which is not related to design directly. Like I learned manufacturing process but it's not helpful to design.' Here the student response suggests a view of competing disciplinary perspectives and a resulting inability to synthesis disciplinary knowledge. LDS_St_17 appears to further suggest engineering education inhibited a design ability, '3prohibit your design ability'. For DHE_St_13, a requirement to acquire skills and knowledge from different disciplinary perspectives appeared to come at the perceived expense of a deeper understanding of design, 'do I know anything about engineering? My response would usually be, ${ }^{5} \mathrm{No}$, I don't, not at all'. Here the participant appears to lament a limited understanding of one discipline (engineering) at the expense of a deeper understanding of another (design).

DHE_St_12 indicated the ways in which different disciplines approached the dissemination of knowledge, 'the engineering professors tend to see the things or evaluate the things ${ }^{7}$ based on the fixed knowledge, the fixed answer'. Likewise, participant DHE_St_O3 suggested how a requirement to obtain knowledge from more than one discipline was seen as a burden against a perceived necessity to gain disciplinary expertise. DHE_St_O3 suggested knowledge from one discipline was unrelated to that of another within her educational experience, 'should take some classes about engineering which is ${ }^{9}$ not related to design directly. Like I learned manufacturing process but it's not helpful to design.'

$D$-02a. indicated student participants' challenge in reconciling disciplinary perspectives as part of their undergraduate education. Far from a synthesis of approaches (indicated in D-01a. \& DO1b., Synthesis of Disciplinary Perspectives), results indicate how, for some participants, disciplinary knowledge was at odds or in opposition. Taking these and the results above, it may be that if students see conflict or opportunity in an interdisciplinary approach depended upon the students themselves. Where some may have seen opportunity, others saw disciplines as in opposition to one another. 
However, if this is the case, it remains unclear as to why these difference exist, where or by what means these different views may have emerged.

\section{D-03. INSTITUTION \& INTERDISCIPLINARITY}

\section{D-03a. Disciplinary Perspectives Implications for Educational Experience}

The $D$-03. encoding dimension indicated how the representation of different disciplinary perspectives within the institutional context influenced the interdisciplinary student experience. Figure 6 illustrates encoded responses for the sub-category D-03a. (Disciplinary Perspectives Implications for Education Experience, $f=45$ ). As indicated, higher percentage frequencies of encoding were seen in the $D H E$ sample compared to the $L D S$ group.

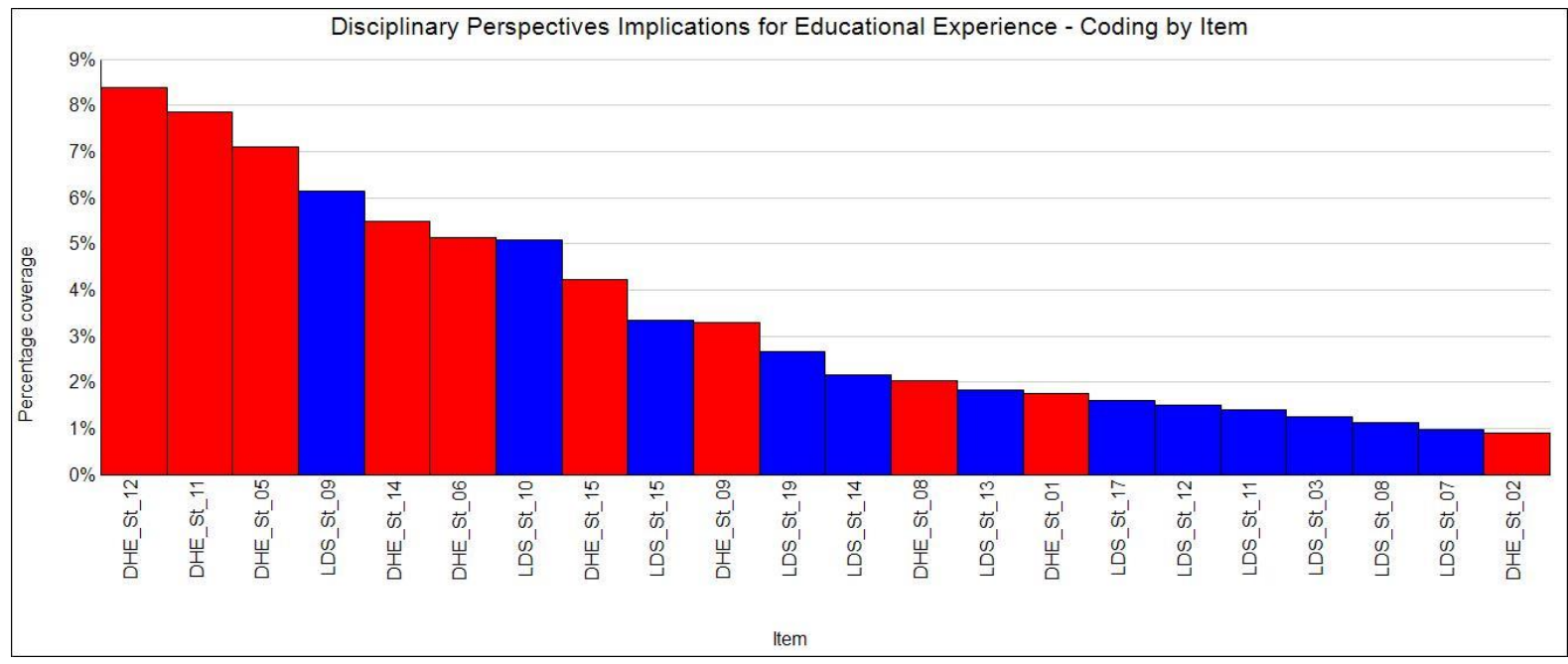

Fig. 6 Percentage encoding frequencies ( $\% f$ ) for $D-03 a$

Table 9 further provides a sample of In Vivo coded for individual student responses within the D-03a sub-category.

Table 9 In Vivo encoding of sub-category $D-03 a$

\begin{tabular}{|c|c|c|}
\hline Code & $\begin{array}{l}\text { D03a Disciplinary Perspectives \& Implications for Educational } \\
\text { Experience }\end{array}$ & In Vivo Coding \\
\hline \multirow{2}{*}{$\begin{array}{l}\text { DHE } \\
\text { St_12 }\end{array}$} & $\begin{array}{l}\text { Scholarship is very important and you have the follow the }{ }^{I} \text { way of } \\
\text { thinking of the professors because even inside the design field one } \\
\text { professor the opinion is different from another professor. }\end{array}$ & $\begin{array}{l}\text { 1. way of thinking of } \\
\text { the professors }\end{array}$ \\
\hline & $\begin{array}{l}\text { ID [industrial design] professors and HFE [human factors engineering] } \\
\text { professors provide together. I think there are too }{ }^{2} \text { less cooperation } \\
\text { between ID professors and ergonomics professors, so that's also get } \\
\text { influenced by that. }\end{array}$ & $\begin{array}{l}\text { 2. less cooperation } \\
\text { between }\end{array}$ \\
\hline $\begin{array}{l}D H E \\
S t \_l 1\end{array}$ & $\begin{array}{l}\text { In HFE [human factors engineering] there not as many students in ID } \\
\text { track, so it is different. Also, in ID classes, maybe, we have to do } \\
\text { presentation, PPT Design, and presentation skill, everything is } \\
\text { important and }{ }^{3} \text { everyone thinks it is important but in HFE, it does not } \\
\text { matter. }\end{array}$ & $\begin{array}{l}\text { 3. everyone thinks it is } \\
\text { important but in HFE, } \\
\text { it does not matter }\end{array}$ \\
\hline
\end{tabular}




\begin{tabular}{|c|c|c|}
\hline $\begin{array}{l}\text { DHE } \\
\text { St_05 }\end{array}$ & $\begin{array}{l}\text { tried to apply the things I learned from there in design track some } \\
\text { students or professors }{ }^{4} \text { wouldn't kind of approve of that method because } \\
\text { they thought that design comes first, then the ergonomics. }\end{array}$ & $\begin{array}{l}\text { 4. wouldn't kind of } \\
\text { approve. }\end{array}$ \\
\hline \multirow{2}{*}{$\begin{array}{l}L D S_{-} \\
\text {st_09 }\end{array}$} & \multirow{2}{*}{$\begin{array}{l}\text { so that you know, there will be differentiation there already because it's } \\
5 \text { different people doing it. } \\
\text { my personal experience that there is the }{ }^{6} \text { engineering crowd and there is } \\
\text { the design crowd. }\end{array}$} & $\begin{array}{l}\text { 5. different people } \\
\text { doing it }\end{array}$ \\
\hline & & $\begin{array}{l}\text { 6. engineering crowd } \\
\text { and there is the design } \\
\text { crowd }\end{array}$ \\
\hline$D H E$ & $\begin{array}{l}\text { Student does not use two major more effectively because we did not } \\
\text { learn much things up to majors because we }{ }^{7} \text { had to do two, we had to }\end{array}$ & 7. had to do two \\
\hline$S t \_14$ & $\begin{array}{l}\text { take two majors, it's the time and }{ }^{8} \text { time problem, resource problem and } \\
\text { so it's really hard to tell. }\end{array}$ & $\begin{array}{l}\text { 8. time problem, } \\
\text { resource problem }\end{array}$ \\
\hline
\end{tabular}

DHE_St_12 indicated how an instructor's disciplinary bias implicated the ways in which project work was conducted. This seemed to suggest student approach to project works was dependent upon the discipline specific criteria faculty applied to evaluate student project outcomes. Likewise, $D H E \_S t \_11$ spoke of differences in disciplinary expectations as influence upon course deliverables, " thinks it is important but in HFE [Human Factors Engineering], it does not matter.' DHE_St_05 indicated how faculty from different disciplinary perspectives disapproved of the approaches taken by their peers, '“wouldn't kind of approve of that method'. In a related way, DHE_St_14 expressed concern over how differing disciplinary requirements necessitated increased time and effort, 'it's the time and ${ }^{8}$ time problem, resource problem.' In contrast, LDS_st_09 spoke of how disciplinary perspectives implicated a separation within the school, " ${ }^{6}$ engineering crowd and there is the design crowd.'

An inability for faculty from different disciplines to agree the methods and approaches taken, and the importance of these approaches to a holistic programme of study, appeared to result in students altering their work in order to satisfy the expectations of different instructors/tutors from differing disciplinary perspectives. In a related way, participants also voiced concern over how a lack of cooperation between disciplines at an institutional level compounded a requirement for adjustment to course deliverables dependent upon the type of course and/or instructor.

\section{D04 EDUCATION \& INTERDISCIPLINARITY}

\section{D-04a Relevance of Interdisciplinary Education}

Figure 7 illustrates frequencies of encoding (\%f) for discussion of the relevance of an interdisciplinary education. 


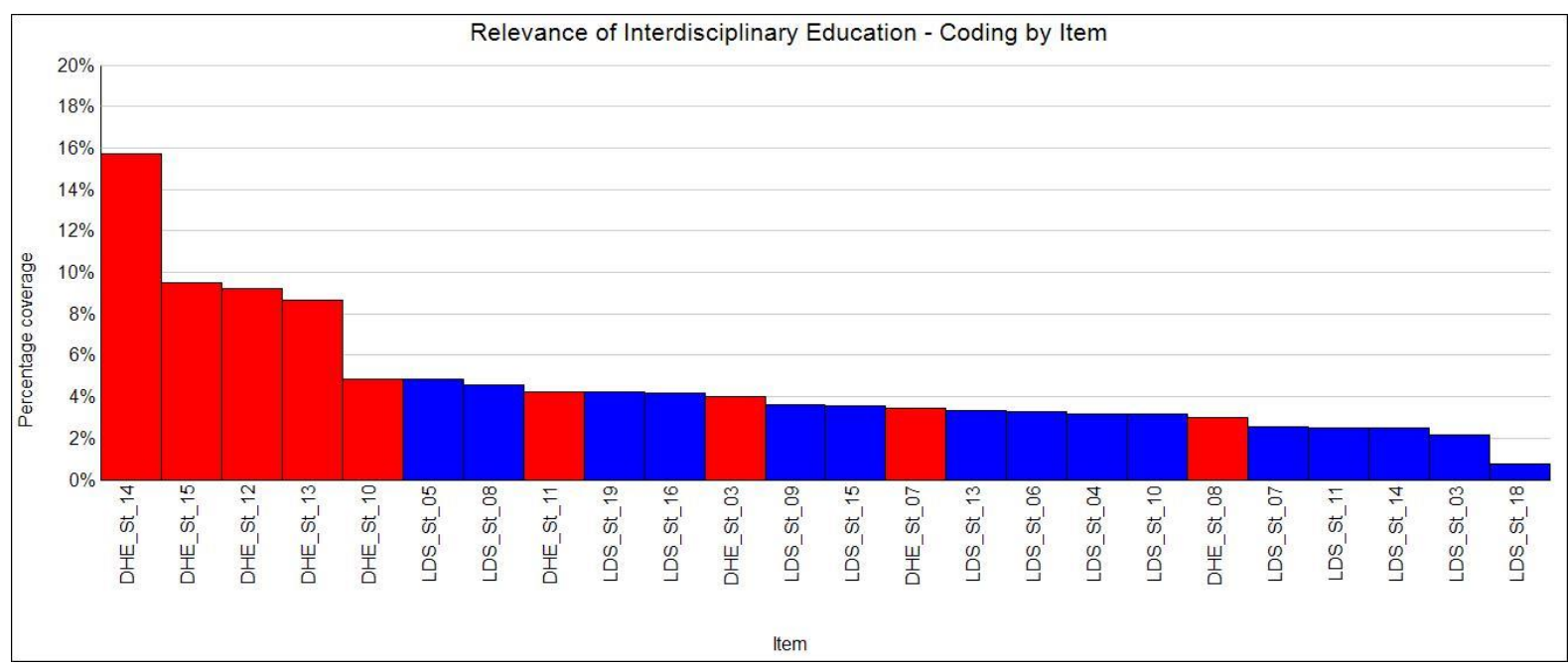

Fig. 7 Percentage encoding frequencies (\%f) for $\mathrm{D}-04 a$

The five participants with the highest frequency of encoding where found to come from the $D H E$ sample (Figure 7). This result may indicate the DHE students were more concerned with the appropriateness of their interdisciplinary education in terms employment compared to their $L D S$ counterparts. This may be derived from certain cultural and/or societal differences between the Korean and UK institutions. For example, it appeared that the Korean participants put more emphasis upon the specialised nature of industry i.e. how an interdisciplinary education may inhibit employability due to a more discipline specific industry context.

Table 10 illustrates results of In Vivo encoding for the five DHE participants with the highest frequencies $(\% f)$.

Table 10 In Vivo encoding of sub-category $D-04 a$

\begin{tabular}{|c|c|c|}
\hline Code & D04a Relevance of Interdisciplinary Education & In Vivo Coding \\
\hline $\begin{array}{l}D H E \\
S t \_14\end{array}$ & $\begin{array}{l}\text { But we did }{ }^{I} \text { not learn the deep side of ergonomics, so we could just take } \\
\text { something from ergonomics and combine it with design. } \\
\text { When I have my career then I }{ }^{2} \text { cannot say that it's really helped me } \\
\text { because I have to focus on one specific thing when I get a job. }\end{array}$ & $\begin{array}{l}\text { 1. not learn the deep } \\
\text { side of ergonomics } \\
\text { 2. cannot say that it's } \\
\text { really helped } \\
\text { 3. have to focus on one } \\
\text { specific thing }\end{array}$ \\
\hline $\begin{array}{l}D H E \\
S t \_15\end{array}$ & $\begin{array}{l}\text { I feel }{ }^{4} \text { some kind of confusion because they might feel that they } \\
\text { [students] don't know what is their major and } 5 \text { I didn't know very well } \\
\text { about the major courses. }\end{array}$ & $\begin{array}{l}\text { 4. some kind of } \\
\text { confusion } \\
\text { 5. I didn't know very } \\
\text { well }\end{array}$ \\
\hline $\begin{array}{l}D H E \\
S t_{-} 12\end{array}$ & $\begin{array}{l}\text { That those two interdisciplinary research activities are well mixed or } \\
{ }^{6} \text { well combined and come out with a good achievement then it will be } \\
{ }^{7} \text { much more beneficial. }\end{array}$ & $\begin{array}{l}\text { 6. well combined } \\
\text { 7. much more } \\
\text { beneficial }\end{array}$ \\
\hline
\end{tabular}


Two IDs [industrial design] and three Engineering [students] and they are second major or ergonomics and that course ${ }^{8} I$ could see synergy DHE with engineering much more than when I was a sophomore.

St_13

And I have ${ }^{9}$ some conflict or some problem with engineering aspects already, so this ${ }^{10}$ strength is meaningless when I have limited Industrial Design skills. do both of them so it's quite... because we need to use some time to study more engineering or ergonomics so maybe ${ }^{12}$ our specialty is quite lacking.
8. I could see synergy

9. some conflict or some problem

10. strength is meaningless

11. ambiguous that we're designers or engineers

12. our specialty is quite lacking

DHE_St_14 indicated the ways in which an interdisciplinary education had been unhelpful in providing a required depth of knowledge, 'not learn the deep side of ergonomics'. Likewise, DHE_St_13 suggested frustration at a lake of core disciplinary skills due to a requirement to acquire skills from another discipline [engineering], 'strength is meaningless when I have limited Industrial Design skills'. DHE_St_10 indicates concern for a specialised ability due to a requirement to acquire a deeper, disciplinary range of skills and knowledge, 'our specialty is quite lacking.'

However, These findings conflicted with those indicating both acquisition $(D-01 a$. $)$ and synthesis $(D-$ 01b.) of disciplinary knowledge. Participants also discussed how their interdisciplinary profile may negatively impact employability. For example, DHE_St_15 expressed concern over employer misunderstanding of professional profile, 'they might feel that they [employer] don't know what is their [student] major'. DHE_St_10 spoke of an ambiguity that may lead to problems with professional identity in the workplace, 'quite ${ }^{11}$ ambiguous that we're designers or engineers'.

These results indicated that participants saw the challenge of an interdisciplinary education as relating to concern for limited specialised skills and knowledge, together with concerns over how an interdisciplinary education would be seen and understood by a discipline specific and specialised industrial workforce. Interestingly, as indicated within encoding frequencies, this was truer for the DHE students. It may be that there are particular cultural and societal differences working as drivers for concerns of the relation between interdisciplinarity and employability.

\section{Discussion}

With a focus upon industrial design, the current study has explored how approaches to interdisciplinary education at undergraduate level may influence the student learning experience. To achieve this, a grounded qualitative content analysis, followed by an analysis of encoding frequencies, indicated four board themes within the interview data: acquisition of interdisciplinary knowledge ( $D$ 01., $f=155$ ) as most frequently discussed by participants, followed by student attitudes as implicating engagement with interdisciplinarity (D-02., $f=106)$, institution as influence upon the success of interdisciplinary programmes (D-03., $f=84)$ and educational provision $(D-04, f=78)$. Through the 
identification of sub-categories we were able to explore the four themes at a greater level of granularity. This was supported by a second-round of In Vivo encoding.

Results indicated concern for acquisition of interdisciplinary knowledge as most frequently discussed by both sample groups of participants: School of Design \& Human Engineering, UNIST, Korea (DHE) \& Loughborough Design School, Loughborough University, UK, (LDS). Further analysis indicated three aspects of knowledge acquisition (identified as sub-categories): awareness of disciplinary perspectives (D-01a., $f=55)$, synthesis of perspectives $(D-01 b ., f=53)$ and application as catalyst for interdisciplinary learning (D01c., $f=47)$.

In terms participant awareness of disciplinary perspectives (D-01a.), findings indicated student discussion of how interdisciplinary learning provided greater opportunities for improved design work. However, as indicated in the frequency analysis, awareness was not equally distributed among participants. This would agree with Mansilla's and Gardener (2003) and Lettuca et al's (2013) notion of Awareness of Disciplinarity as measure for interdisciplinary competence. The student discussion of disciplinary perspectives indicated they possessed knowledge from the disciplines within their courses of study (i.e. industrial/product design, ergonomics, mechanical engineering) to potentially integrate such knowledge for the benefit of their design works. However, this ability appeared truer for some students than others.

The above also relates to results indicating synthesis of disciplinary perspectives $(D-01 b$.). Here participants discussed their ability to synthesise disciplinary knowledge and skills. A balanced approach and wider understanding along with seeing the problem from various angles all emerged within the discussion to indicate synthesis. These results relate to Lattuca's (op cit.) notion of Appreciation of Disciplinary Perspectives, with students indicating an ability to understand how differing disciplinary perspectives may integrate to inform a more holistic understanding. However, as with awareness, positive response towards synthesis was not always the case and not universally identified among the student samples. While some participants indicated an ability to synthesise disciplinary perspectives, others indicated they felt challenged by the differences between disciplines. Given the variation in ability to synthesise disciplinary knowledge from students in the same programmes of study, future work may wish to explore individual student aptitude and interest as driver for interdisciplinary knowledge acquisition.

In terms acquisition of disciplinary knowledge (D-01.), application as means to potentiate interdisciplinary learning was identified within the results $(D-01 c$.). Participants discussed the importance of application as means to provide opportunities to take ownership of interdisciplinary learning. This appeared to relate to Newell's (2001) notion of Integrative Skill in the students' ability to approach and solve problems greater than the sum of their disciplinary parts. Somewhat uniquely for design, this result indicates the ways in which students within the applied discipline of design responded well to interdisciplinarity through opportunities to integrate disciplinary knowledge 
through application within their own project works. As an applied field, design may be in an advantageous position in its endeavours towards interdisciplinary education if application can be used as leverage for increased interdisciplinary knowledge acquisition. Future studies may wish to further explore application's role in interdisciplinary education towards the development of best practices.

Student attitudes \& interdisciplinarity was also identified within our analysis (D-02.). However, only the sub-category Conflicting Disciplinary Perspectives (D-02a.) reached an encoding frequency higher than $40(f=59)$. That is, students tended to discuss the different disciplines as in opposition to one another; an attitude of one discipline against another. While both synthesis of disciplinary perspectives $(D-01 b$. $)$ and integration through application $(D-01 c$.$) was evident in the findings, this$ result indicated the challenge of disciplinary reconciliation. However, this was not true of all students. An interesting future line of enquiry may wish to explore relations between attitudes, student interests and views on interdisciplinarity within their educational experience.

A third theme to emerge from the encoding of data we termed Institute \& Interdisciplinarity (D-03., $f=84$ ). Here participants discussed differing institutional disciplinary perspectives in relation to their impact upon interdisciplinary learning $(D-03 a$., $f=45)$. Student participants from the $D H E$ sample, in particular, discussed how differences in disciplinary perspectives at an institutional level resulted in the readjustment of project works and outcomes dependent upon the particular disciplinary approaches of instructors/tutors. For some, this separation also extended to a perceived fragmentation within the educational institution itself along disciplinary lines, with implications for student perception of their interdisciplinary education (D-02a, Conflicting Disciplinary Perspectives).

Finally, relevance of interdisciplinary education was identified as implicit in the success of interdisciplinary endeavours (D-04a Relevance of interdisciplinary education). This result indicated some participants appeared to struggle with appreciation of interdisciplinary learning due to a belief that an interdisciplinary approach may not lead to a required depth of knowledge in any single discipline. Likewise, and in a related way, interviewees appeared concerned as to how an interdisciplinary education would be valued by a discipline orientated industry. This was particularly true for the DHE student sample. This result thus contradicted those that indicated awareness (D-01a.) and synthesis $(D-O 1 b$. $)$ as indicators of successful interdisciplinary learning, suggesting how students within the same programme of study may see more or less relevance in their interdisciplinary education.

\section{Conclusions}

Our findings appear to provide evidence of interdisciplinary learning at both institutions, as indicated through data that revealed an awareness of disciplinary knowledge and evidence of its integration and application. However, other findings contradicted this. In particular, students indicated institutional and programme structure challenges to interdisciplinary learning. Notably, the disciplinary perspectives of instructors/tutors and their associated expectations in terms of project outcomes 
together with concerns over the depth of interdisciplinary learning and related impact upon employment after graduation were seen as challenges to an interdisciplinary education at undergraduate level.

Results also indicated the role of application as a driver for interdisciplinary learning. This finding may be of particular interest to the applied field of design. Through application design students may be best placed to synthesise and integrate disciplinary approaches, knowledge and perspectives for the benefit of their project work and holistic learning experiences. Given the particular applied nature of the design discipline, further studies may wish to explore how application may best be used as driver for an interdisciplinary design education. However, our findings also indicate application as suitable tool in the context of design pedagogy, but only when accompanied by institutional interdisciplinarity in terms both course instructors and related project expectations.

The success of interdisciplinary endeavours at undergraduate level appear to be dependent upon how instructors from different disciplines integrate in the provision of educational programmes. Without this, as indicated by Self and Baek (2016), interdisciplinary learning is limited to those students with the greatest attitude or predisposition towards interdisciplinarity. The appropriateness of interdisciplinary education may also depend upon the types of students attending programmes of study, their related profiles, attitudes, particular, existing skill-set, motivations and openness to an interdisciplinary approach. Future studies may wish to explore student profiles, attitudes and skills as related to a predisposition for an interdisciplinary education. Within this, cultural context and societal norms appear important considerations when endeavouring interdisciplinary approaches to design education.

The current study has gone some way to understand the opportunities and challenges to an interdisciplinary education at undergraduate level from the student learning perspective. However, our approach has limitations. First, our findings have drawn from only two institutions. More studies are required of various institutions, programmes of study and educational approaches. These should aim to explore the ecologies of interdiscipliarity (i.e. cultural, systemic, societal), in order to build a theoretical foundation for interdisciplinarity in design education. Second, in our interview approach we rely upon a relation between what the interviewees say and what actually takes place within the interdisciplinary programmes of study with regards learning experiences. From our study we do not know the extent to which what the students say reflects actual activities, conditions and experiences. Further studies may which to take other approaches (i.e. shadowing, observations) to understand learning experience.

These limitations notwithstanding, the current study has provided an indication of the barriers to and potential opportunities for interdisciplinary approaches to undergraduate education in design. More studies are now required to lay the foundations for successful programmes of study to address the increasingly complexity of problems now facing the future of design. 


\section{References}

Adams, R. S., Turns, J., \& Atman, C. J. (2003). Educating effective engineering designers: the role of reflective practice. Design Studies, 24(3), 275-294.

Bingham, G., A., Southee, D., J., \& Page, T. (2015). Meeting the expectation of industry: an integrated approach for the teaching of mechanics and electronics to design students. European Journal of Engineering Education, 40(4), 410-431.

Carulli, M, Bordegoni, M, \& Cugini, U. (2013). An Intergrated Framework to Support Design \& Engineering Education. International Journal of Engineering Education, 29(2), 291-303.

Goel, V. (2001). Dissociation of Design Knowledge. In C. Eastman, M. McCracken \& W. Newstetter (Eds.), Design Knowing and Learning: Cognition in Design Education, 221-240. London: Elsevier.

Jaeger, A, Mayrhofer, W, Kuhlang, P, \& Matyas, K. (2013). Total Immersion: Hands and Heads-On Training in a Learning Factory for Comprehensive Industrial Engineering Education. International Journal of Engineering Education, 29(1), 23-32.

Kang, N. (2008). Activation plan for the convergence study of scientific technology \& humanities and social sciences. Ministry of education, science and technology.

Kaygan, P., \& nar. (2014). 'Arty' versus 'Real' Work: Gendered Relations between Industrial Designers and Engineers in Interdisciplinary Work Settings. The Design Journal, 17(1), 73-90.

Kim, K., Kim, N., Jung, S., Kim, D.Y., Kwak, Y., \& Kyung, G. (2012). A Radically Assembled Design-Engineering Education Program with a Selection and Combination of Multiple Disciplines. International Journal of Engineering Education, 28(4), pp. 904-919.

Klein, J. (1990). Interdisciplinarity: History, Theory, and Practice. Detroit: Wayne State University Press.

Klein, Julie , \& Newell, W. (1998). Advancing Interdisciplinary Studies. In W. Newell (Ed.), Interdisciplinarity: Essays From the Literature. New York: College Entrance Examination Board.

Kolb, D. (2014). The Structure of knowledge Experiential Learning: Experience as the Source of Learning and Development (2nd ed., pp. 153-192). New Jersey: Pearson Education Inc.

Lattuca, L, Knight, D, \& Bergom, I. (2013). Developing a Measure of Interdisciplinary Competence. International Journal of Engineering Education, 29(3), 726-739.

Lattuca, L. R., \& Knight, D. B. (2010). In the eye of the beholder: Defining and studying interdisciplinarity in engineering education. Proceedings of the $117^{\text {th }}$ annual conference of the American Society of Engineering Education. Louisville, KY: American Society for Engineering Education.

Lattuca, L. R. (2001). Creating Interdisciplinarity: Interdisciplinary Research and Teaching Among College and University Faculty. Nashville: Vanderbilt University Press.

Lattuca, L. R., Voight, Lois J., \& Fath, K., Q. (2004). Does Interdisciplinarity Promote Learning? Theoretical Support and Researchable Questions. Review of Higher Education, 28(1), 23-C.

Lee, J. (2014). The Integrated Design Process from the Facilitator's Perspective. International Journal of Art \& Design Education, 33(1), 141-156.

Mansilla, V., \& Duraising, E. (2007). Targeted Assessment of Students' Interdisciplinary Work: An Empirically Grounded Framework Proposed. The Journal of Higher Education, 78(2), 215-237. 
Mansilla, V, \& Gardner, H. (2003). Assessing Interdisciplinary Work at the Frontier: An empirical exploration of "symptoms of quality". In G. Origgi \& C. Heintz (Eds.), Rethinking Interdisciplinarity. Harvard, Cambridge MA: Harvard University.

Mok, Y. H. (2009). Korea education in the age of knowledge convergence. Paper presented at the Autumn conference of Korean educational reseach association.

Newell, W. (2001). A Theory of Interdisciplinary Studies. Issues in Integrative Studies, 19, 1-25.

Norman, D. (2010). Why Design Education Must Change. Core77.

Norman, D, \& Klemmer, S. (2014). State of Design: How Design Education Must Change. Core77.

Oehlberg, L., Leighton, I., \& Agogino, A. (2012). Teaching Human-Centred Design Innovation across Engineering, Humanities and Social Sciences. International Journal of Engineering Education, 28(2), 484-491.

Park, J. S. (2009). A strengthening plan for the education competitiveness to ensure the global competition.

Repko, A. (2012). Interdisciplinary Research: Process and Theory (second ed.). New York: SAGE Publications, Inc.

Saldana, J. (2013). In Vivo Coding, The Coding Manual for Qualitative Research, 91-96. London: SAGE Publications Ltd.

Self, J., A., \& Baek, J., S. (2017). Interdisciplinarity in design education: understanding the undergraduate student experience. International Journal of Technology and Design Education, 27(3), 459-480.

Thompson, M. (2009). Increasing the Rigor of Freshman Design Education. In proceedings of iasdr09, Seoul, Korea.

Tolbert, D., \& Daly, S., R. (2013). First-Year Engineering Student Perceptions of Creative Opportunities in Design. International Journal of Engineering Education, 29(4), 879-890.

Yim, H, L., K, Brezing, A., Lower, M., \& Feldhusen, J. (2011). Learning from an Interdisciplinary and Intercultural Project-Based Design Course. Proceedings of the International Conference on Engineering and Product Design Education, City University, London, UK. 